\title{
Ainda conectado: o PT e seus vínculos com a sociedade
}

\author{
Oswaldo Amaral \\ Departamento de Relações Internacionais \\ Escola Superior de Propaganda e Marketing
}

Resumo: O objetivo deste trabalho é mostrar que o Partido dos Trabalhadores (PT) continua mantendo vínculos sólidos com a sociedade civil organizada e a atrair filiados, apesar das transformações pelas quais passou a partir da segunda metade da década de 1990, especialmente sob aspecto ideológico. programático. A partir da análise de dados sobre os filiados e a organização partidária, bem como de surveys realizados com os delegados petistas reunidos em encontros nacionais entre 1997 e 2007 , mostramos que o PT continua permeável à participação de atores da sociedade civil organizada assim como teve um crescimento significativo no número de membros durante os anos do governo Lula.

Palavras-chave: Partido dos Trabalhadores; organização partidária; partidos políticos; bases partidárias.

Abstract: The main aim of this paper is to show that the Workers' Party (PT) continues to be strongly attached to civil society organizations and capable of attracting members after a series of programmatic and ideological changes in the last 15 years. Through the evaluation of membership and organizational data and also the analysis of surveys conducted among PT's delegates between 1997 and 2007, we show that the party still has strong connections to civil society organizations and increased significantly its number of members during Lula's government.

Keywords: Workers' Party; party organization; political parties; party bases 


\section{Introdução ${ }^{1}$}

A formação do Partido dos Trabalhadores (PT) esteve diretamente ligada a atores da sociedade civil organizada, como sindicalistas, militantes de grupos de esquerda e líderes de movimentos populares urbanos e membros das Comunidades Eclesiais de Base (CEBs). Em que pesem as especificidades da formação do partido nas unidades da Federação (UFs), há praticamente um consenso na literatura a respeito da forte vinculação da agremiação com movimentos sociais nos seus primeiros anos, o que levantou a curiosidade de muitos analistas dado que o PT conseguiu canalizar, no plano institucional, uma série de demandas políticas reprimidas de diferentes atores sociais em um contexto mais amplo de crise de representação vivida pelos partidos políticos, especialmente na Europa Ocidental (LAWSON e MERKL, 1988; KATZ, MAIR et al, 1992). Esse foi um dos elementos que levaram autores como Meneguello (1989) e Keck (1991) a qualificar o PT como uma novidade na política brasileira.

O objetivo geral deste trabalho é mostrar que o PT continua mantendo vínculos sólidos com a sociedade civil organizada e a atrair filiados, apesar das transformações pelas quais passou a partir da segunda metade da década de 1990, especialmente no aspecto ideológico-programático. Como objetivos específicos, buscamos desvelar algumas importantes transformações e no perfil social das lideranças petistas na organização partidária interna, como a maior capilarização de suas estruturas. Com isso, procuramos trazer mais elementos para o estudo da organização interna dos partidos no Brasil, uma área sub-representada na Ciência Política nacional (NICOLAU, 2010), em que pesem os recentes esforços de Roma (2006), Ribeiro (2008), Braga (2008) e Amaral (2010). As hipóteses que norteiam este artigo são as de que o partido continua permeável à participação de atores da sociedade civil organizada, capaz de atrair filiados, e apresenta um padrão de alteração entre suas lideranças causado, em parte, pela ampliação da inserção do PT na política institucional a partir da década de 1990.

Trabalhamos com dois conjuntos de indicadores empíricos. O primeiro deles envolve o número de filiados ao PT e de Diretórios Municipais (DMs) e Comissões Provisórias Municipais (CPMs) ao longo do tempo². O segundo, envolve dados de

\footnotetext{
1 Este artigo é uma versão alterada de um capítulo da tese de doutorado "As transformações na organização interna do Partido dos Trabalhadores entre 1995 e 2009", defendida no Programa de Pós. Graduação em Ciência Política da Universidade Estadual de Campinas (Unicamp) em dezembro de 2010. Uma versão preliminar deste texto foi apresentada no VI Congresso do Ceisal, em Toulouse, em julho de 2010. Agradeço a Rachel Meneguello, Maria do Socorro Braga, André Singer, Leôncio Martins Rodrigues, Valeriano Costa, Flavia Freidenberg, Margarita Batlle e ao parecerista de Opinião Pública pelas críticas e sugestões.

2 Demos preferência, aos dados fornecidos ou publicados pelo PT, e não aos disponíveis no Tribunal Superior Eleitoral (TSE). Essa opção deu-se pelo fato de os números do TSE serem, muitas vezes, superestimados, pois os partidos não contam com um controle rígido daqueles que já se desligaram das
} 
surveys realizados pela Fundação Perseu Abramo (FPA) e pelo autor com as lideranças petistas em Encontros (ENs) e Congressos Nacionais (CNs) do partido em 1997, 1999, 2001, 2006 e 2007.

O artigo está organizado em três partes, determinadas de acordo com os objetivos enunciados e a partir da compreensão, acompanhando Alcántara Saez e Freidenberg, de que desvelar as características da base de filiados e dos grupos que compõem um partido político constitui elemento fundamental para entendermos sua organização interna (2003, p. 16). Na primeira parte, o foco está na base de filiados do partido e na estrutura de incentivos que determinou as transformações dessa base. Damos especial atenção às regras de filiação, à política de captação de novos membros e às mudanças institucionais, assim como ao contexto político mais amplo que contribuíram, ainda que de maneira indireta, para as alterações identificadas. Na segunda, nos concentramos nos dados sobre a liderança petista, no seu perfil social e nas suas relações com os movimentos e as organizações sociais. Ao final, concluímos o artigo privilegiando a articulação entre os resultados encontrados e a literatura em torno dos modelos partidários e sobre o PT, em especial os trabalhos de Meneguello (1989), Keck (1991), Novaes (1993), Rodrigues (1997), Ribeiro (2008) e Hunter (2007; 2010).

\section{A base de filiados}

Em março de 1982, logo após o enorme esforço para a regularização do partido, uma circular da então Secretaria de Filiação e Nucleação (SFN) do PT estabeleceu metas bastante ambiciosas quanto ao recrutamento de filiados: atingir 1 milhão de membros e organizar o partido em pelo menos $40 \%$ dos municípios de cada estado até julho daquele ano; fazer com que os diretórios estaduais assumissem a tarefa de filiação e organizar um balanço da situação organizacional do partido em cada UF (KECK, 1991, p. 127-128). Os dados da Tabela 1, que contempla a evolução no número de filiados ao longo do tempo, e os dados da Tabela 2, que demonstra a evolução do número de DMs, indicam que o partido levou mais de 20 anos para alcançar os objetivos estabelecidos pela SFN.

agremiações e não apresenta um número preciso de desfiliados, conforme exigido pela lei nº 9096/95 (a introdução de um sistema eletrônico, o Filiaweb, a partir de 2009, tende a reduzir essas discrepâncias). Além disso, o PT realizou um recadastramento dos seus filiados entre os anos de 2001 e 2003 e considera como membros apenas as pessoas que possuem registro no Cadastro Nacional de Filiados e são portadoras da carteira de identificação do partido. Isso explica também porque decidimos realizar análises mais detalhadas com os números de filiados apenas a partir de 2003. Como reconhece a própria Secretaria de Organização (Sorg) do partido, os números a partir desse ano apresentam um maior grau de confiabilidade. Com relação aos dados sobre os DMs e CPMs, a lógica se mantém. A partir do processo de recadastramento de filiados, o PT também teve como descobrir a real dimensão da sua capilaridade organizativa. 
A análise dos dados sobre a evolução dos filiados ao longo do tempo evidencia a dificuldade de interiorização e implantação do PT em todos os estados do país, um processo que só se concluiu na primeira década do século XXI. Nesse caso a evolução do número de filiados mostra um processo de expansão da base petista durante os anos 1980 e o início dos anos 1990. No início da década passada, porém, a agremiação realizou um processo de recadastramento de seus membros e considerou como filiados, em 1999 e 2001, aqueles que efetivamente participaram dos processos decisórios do partido. Em 1999, participaram dos encontros de base 212.320 membros do partido e, em 2001, participaram do primeiro Processo de Eleições Diretas (PED) 227.461 filiados. Concluído o processo de recadastramento, em 2003, o partido contabilizava 419.941 membros. Desde houve uma grande expansão na base de filiados petista concentrada nos anos de 2003/2005 e 2006/2008, quando o partido passou a contar com 840.108 e 1.387.682 membros, respectivamente, superando a barreira de mais de $1 \%$ do eleitorado $(1,06 \%)$ e transformando-se no segundo partido com o maior número de filiados no Brasil, atrás apenas do Partido do Movimento Democrático Brasileiro $(\mathrm{PMDB})^{3}$. Sobre esse crescimento acelerado nos últimos anos, apresentaremos algumas explicações mais adiante.

Como notou Ribeiro (2008, p. 246), os dados por estado apresentam uma grande heterogeneidade, com algumas UFs mostrando sempre taxas de Filiados por Mil Eleitores (FPME) acima da média nacional, como o Acre e o Rio Grande do Sul, o que demonstra as especificidades de implantação do partido segundo os grupos que organizaram o PT em cada estado (KECK, 1991, p. 117). No entanto, quando olhamos para os dados organizados de maneira a avaliar a distribuição dos filiados petistas entre as regiões do país, algumas alterações importantes devem ser destacadas (Gráfico 1). Até meados dos anos 1990, o PT apresentava uma concentração de filiados muito grande na região Sudeste (em torno de 60\%), enquanto a região era responsável por cerca de $45 \%$ do eleitorado nacional. Essa sobrerrepresentação pode ser explicada pelo próprio processo de formação do partido e seus grupos de origem, em especial os membros de movimentos populares urbanos e sindicalistas. A partir de 1993, identificamos um processo de desconcentração dos filiados que só foi concluído em 2008, quando o PT atingiu uma distribuição de membros entre as regiões muito próxima da configuração do eleitorado brasileiro. A proporção de filiados no Sudeste caiu para cerca de $40 \%$ em 1999 e se manteve assim até 2010. Na segunda metade da década de 1990, as regiões Sul e Centro-Oeste foram as que apresentaram maior crescimento, passando a contar, em 2001, com $21,1 \%$ e $11,4 \%$ dos filiados petistas, enquanto eram responsáveis por $15,7 \%$ e $6,7 \%$ do eleitorado nacional, respectivamente. 0

\footnotetext{
${ }^{3}$ Segundo o TSE, o PMDB contava, em dezembro de 2009, com cerca de 2 milhões de filiados. Dados disponíveis em: http://www.tse.gov.br. Acesso em 20 de fevereiro de 2010.
} 
crescimento no Centro-Oeste foi puxado pelo aumento significativo no número de membros no Mato Grosso do Sul, que, mesmo durante o processo de recadastramento de filiados, manteve altas taxas de Filiados por Mil Eleitores em comparação com os outros estados. A transformação do partido naquele estado com a maior taxa de FPME coincide com as administrações de Zeca do PT entre 1999 e 2006. Na região Sul, o Rio Grande foi o polo de expansão do partido, como já havia notado Singer (2001). A região Nordeste, que ostenta o segundo maior colégio eleitoral do país, foi sistematicamente sub-representada dentro do PT até o ano de 2006, quando apresentou um forte crescimento em relação às outras regiões. Em 2008, passou a contar com $26 \%$ dos filiados e $27,1 \%$ do eleitorado nacional, especialmente impulsionada pelo aumento nas taxas de FPME no Ceará, na Bahia, no Maranhão, em Pernambuco e no Piauí.

A análise do número de filiados nas grandes cidades e capitais brasileiras (Gráfico 2) também apresenta dados importantes. Consideramos grandes cidades aquelas com mais de 200 mil eleitores em 2008 e, para efeito de comparação, mantivemos o mesmo grupo de 80 municípios (G-80) para a agregação dos dados relativos a 2006 e 2004. Os dados mostram que o PT não é mais um partido com membros concentrados apenas em grandes centros urbanos, como afirmaram Keck (1991, p. 128) e Meneguello (1989, p. 80) ao analisarem os dados dos filiados relativos ao estado de São Paulo nos anos 1980. Em 2004, o G-80 contabilizava $41,6 \%$ dos filiados e $37,1 \%$ dos eleitores brasileiros. Em 2006, a proporção permaneceu praticamente inalterada e, em 2008, as capitais e as cidades com mais de 200 mil eleitores contavam com 39,3\% dos filiados ao partido e os mesmos $37,1 \%$ do eleitorado nacional. O cruzamento desses números com as ondas de expansão descritas anteriormente nos leva concluir que, entre 2006 e 2008, o crescimento do número de filiados ao PT deu-se em maior intensidade nos municípios com menos de 200 mil eleitores. Embora não tenhamos dados relativos ao número de filiados por município nos anos 1990, há evidências de que esse processo de expansão organizativa rumo ao interior tenha se acelerado a partir da segunda metade daquela década: entre 1993 e 2000, a porcentagem de municípios em que o PT estava organizado cresceu de cerca de $40 \%$ para mais de $70 \%$, atingindo, em 2009, quase $100 \%$ (Tabela 2). O crescimento na proporção de cidades com vereadores petistas ilustra bem o aumento da penetração do partido no interior do país. O PT elegeu, em 1996, vereadores em $21 \%$ das cidades brasileiras e, em 2008, obteve representantes em 47\% dos municípios. Apesar de mais competitivo nos pequenos municípios, o PT ainda está longe de rivalizar com o PMDB, que elegeu vereadores em $72 \%$ das cidades brasileiras nas últimas eleições locais ${ }^{4}$ de 2008.

\footnotetext{
${ }^{4}$ Dados obtidos em Ribeiro (2008, p. 249) e no TSE. Dados disponíveis em: http://www.tse.gov.br. Acesso em 20 de novembro de 2010.
} 
Os dados permitem traçar um interessante quadro das alterações pelas quais passou o PT no que toca à sua base de filiados. O partido que chega ao final dos dois primeiros mandatos do presidente Lula é mais nacional, menos concentrado nos grandes centros urbanos e apresentou um crescimento, entre 2003 e 2009, de 191,7\% na taxa de FPME, enquanto o índice de filiados por eleitor no Brasil manteve-se praticamente inalterado, em torno de 9,5\%5. Embora com indicadores distintos, nossa análise confirma as realizadas por Singer (2010) e Venturi (2010), que apontam a acentuada interiorização e nacionalização do PT durante o governo Lula. Nosso objetivo agora é exibir algumas expliçções para essas transformações.

\footnotetext{
${ }^{5}$ Dados retirados do TSE e referentes aos filiados em outubro de 2002 e dezembro de 2009. Disponíveis em: <http://www.tse.gov.br>. Acesso em: $<20$ de fevereiro de 2010>.
} 


\section{Tabela 1}

Número de filiados e taxa de filiados por mil eleitores (FPME) (1981-2010), por UF

\begin{tabular}{|c|c|c|c|c|c|c|c|c|c|c|c|c|c|c|c|c|c|c|}
\hline & $\begin{array}{l}\text { Fil. } \\
1981\end{array}$ & $\begin{array}{l}\text { FPME } \\
/ 81 \\
\end{array}$ & $\begin{array}{l}\text { Fil. } \\
1984 \\
\end{array}$ & $\begin{array}{l}\text { FPME } \\
/ 84 \\
\end{array}$ & $\begin{array}{l}\text { Fil. } \\
1993 \\
\end{array}$ & $\begin{array}{l}\text { FPME } \\
193 \\
\end{array}$ & $\begin{array}{l}\text { Fil. } \\
2001\end{array}$ & $\begin{array}{l}\text { FPME } \\
101 \\
\end{array}$ & $\begin{array}{l}\text { Fil. } \\
2003\end{array}$ & $\begin{array}{l}\text { FPME } \\
103 \\
\end{array}$ & $\begin{array}{l}\text { Fil. } \\
2005\end{array}$ & $\begin{array}{l}\text { FPME } \\
105 \\
\end{array}$ & $\begin{array}{l}\text { Fil. } \\
2006\end{array}$ & $\begin{array}{l}\text { FPM } \\
\text { E/06 }\end{array}$ & $\begin{array}{l}\text { Fil. } \\
2008 \\
\end{array}$ & $\begin{array}{l}\text { FPME } \\
108 \\
\end{array}$ & Fil. 2010 & $\begin{array}{l}\text { FPME/ } \\
10\end{array}$ \\
\hline$A C$ & 822 & 7,1 & 1264 & 10,9 & 2300 & 9,7 & 1631 & 4,9 & 1863 & 5,1 & 3738 & 9,6 & 4422 & 11,2 & 6125 & 13,8 & 6129 & 13,6 \\
\hline AM & 1904 & 3,5 & 2134 & 3,9 & 5385 & 5,4 & 2173 & 1,5 & 3446 & 2,3 & 7168 & 4,3 & 8434 & 4,9 & 15531 & 8,1 & 15533 & 8 \\
\hline$A P$ & & & 501 & 7,2 & & & 1291 & 5,2 & 2706 & 9,2 & 6902 & 21 & 6885 & 20,5 & 12318 & 32,1 & 12318 & 31,4 \\
\hline PA & 8000 & 5,3 & 8044 & 5,3 & 14400 & 5,5 & 8953 & 2,7 & 17599 & 4,9 & 26263 & 6,6 & 27042 & 6,7 & 60251 & 13,3 & 60767 & 13,2 \\
\hline $\mathrm{RO}$ & 415 & 1,8 & 1437 & 6,2 & 9520 & 14,4 & 1309 & 1,6 & 4068 & 4,6 & 6188 & 6,5 & 6684 & 6,9 & 9741 & 9,5 & 9755 & 9,4 \\
\hline RR & & & & & & & 161 & 0,9 & 406 & 1,9 & 972 & 4,5 & 1048 & 4,8 & 1445 & 5,8 & 1445 & 5,7 \\
\hline TO & & & & & 4031 & 6,5 & 1548 & 2,1 & 3079 & 3,9 & 7124 & 8,5 & 7427 & 8,8 & 12460 & 13,5 & 12543 & 13,7 \\
\hline $\mathbf{N}$ & 11141 & 4,4 & 13380 & 5,3 & 35636 & 6,6 & 17066 & 2,4 & 33167 & 4,3 & 58355 & 7 & 61942 & 7,3 & 117871 & 12,5 & 118490 & 12,3 \\
\hline$A L$ & 1553 & 2,1 & 860 & 1,2 & & & 2130 & 1,4 & 3454 & 2,2 & 6570 & 3,7 & 6609 & 3,7 & 8163 & 4,1 & 8164 & 4,1 \\
\hline $\mathrm{BA}$ & 5000 & 1,2 & 11730 & 2,8 & 42000 & 6,3 & 9853 & 1,2 & 18835 & 2,2 & 39357 & 4,4 & 41049 & 4,6 & 76555 & 8,4 & 76960 & 8,3 \\
\hline CE & 5000 & 2 & 7579 & 3 & 4530 & 1,2 & 8857 & 1,9 & 13964 & 2,9 & 28794 & 5,6 & 33461 & 6,4 & 70297 & 12,5 & 70374 & 12,3 \\
\hline MA & 4000 & 2,8 & 1394 & 1 & & & 2932 & 0,9 & 4988 & 1,5 & 12100 & 3,2 & 12648 & 3,4 & 27026 & 6,5 & 27026 & 6,5 \\
\hline PB & 3500 & 2,7 & 5172 & 4,1 & 7349 & 3,7 & 6810 & 3,1 & 12642 & 5,5 & 23358 & 9,5 & 23201 & 9,3 & 29822 & 11,2 & 29821 & 11,2 \\
\hline $\mathrm{PE}$ & 4500 & 1,8 & 8147 & 3,2 & & & 9570 & 1,8 & 14490 & 2,7 & 32746 & 5,8 & 35728 & 6,3 & 94784 & 15,6 & 94784 & 15,5 \\
\hline $\mathrm{PI}$ & 3200 & 3,3 & 3315 & 3,4 & 7000 & 4,5 & 4004 & 2,4 & 5775 & 3,1 & 11677 & 5,9 & 13149 & 6,5 & 26929 & 12,3 & 26968 & 12,3 \\
\hline RN & 1500 & 1,6 & 2738 & 2,9 & 5578 & 3,8 & 2013 & 1,1 & 3566 & 1,9 & 6111 & 3 & 6220 & 3,1 & 9677 & 4,5 & 9688 & 4,4 \\
\hline SE & 800 & 1,7 & 1236 & 2,6 & 3260 & 3,7 & 2439 & 2,2 & 4236 & 3,7 & 11121 & 9 & 11815 & 9,4 & 17065 & 12,5 & 17065 & 12,4 \\
\hline
\end{tabular}


OPINIÃO PÚBLICA, Campinas, vol. 17, no 1, Junho, 2011, p.01-44

\begin{tabular}{|c|c|c|c|c|c|c|c|c|c|c|c|c|c|c|c|c|c|c|}
\hline & \begin{tabular}{|l} 
Fil. \\
1981 \\
\end{tabular} & $\begin{array}{l}\text { FPME } \\
/ 81\end{array}$ & $\begin{array}{l}\text { Fil. } \\
1984 \\
\end{array}$ & $\begin{array}{l}\text { FPME } \\
/ 84 \\
\end{array}$ & $\begin{array}{l}\text { Fil. } \\
1993 \\
\end{array}$ & $\begin{array}{l}\text { FPME } \\
193 \\
\end{array}$ & $\begin{array}{l}\text { Fil. } \\
2001 \\
\end{array}$ & \begin{tabular}{|l|} 
FPME \\
01 \\
\end{tabular} & \begin{tabular}{|l|} 
Fil. \\
2003 \\
\end{tabular} & $\begin{array}{l}\text { FPME } \\
103\end{array}$ & \begin{tabular}{|l} 
Fil. \\
2005 \\
\end{tabular} & $\begin{array}{l}\text { FPME } \\
105\end{array}$ & $\begin{array}{l}\text { Fil. } \\
2006 \\
\end{array}$ & $\begin{array}{l}\text { FPME } \\
106 \\
\end{array}$ & Fil. 2008 & $\begin{array}{l}\text { FPME } \\
108 \\
\end{array}$ & Fil. 2010 & \begin{tabular}{|l} 
FPM \\
E/10 \\
\end{tabular} \\
\hline NE & 29053 & 1,9 & 42171 & 2,8 & 69717 & 2,9 & 48608 & 1,6 & 81950 & 2,7 & 171834 & 5,2 & 183880 & 5,5 & 360318 & 10,2 & 360850 & 10,1 \\
\hline DF & & & 2200 & 3 & 6972 & 7,8 & 6440 & 5 & 8640 & 5,6 & 25991 & 17,1 & 26129 & 16,5 & 34803 & 20,9 & 34803 & 19,9 \\
\hline $\mathrm{GO}$ & 5600 & 2,7 & 7752 & 3,8 & 16350 & 6,5 & 5487 & 1,7 & 8085 & 2,4 & 17399 & 4,8 & 18537 & 5 & 28632 & 7,4 & 28630 & 7,3 \\
\hline MS & 2000 & 2,7 & 741 & 1 & 4727 & 4,2 & 10525 & 7,9 & 15004 & 10,6 & 35537 & 23,8 & 36234 & 23,9 & 42939 & 26,6 & 42910 & 26,1 \\
\hline MT & & & 2573 & 4,4 & 4000 & 3,3 & 3482 & 2,1 & 6911 & 4 & 15062 & 8,2 & 15685 & 8,4 & 23417 & 11,8 & 23461 & 11,6 \\
\hline C & 7600 & 2,2 & 13266 & 3,9 & 32049 & 5,6 & 25934 & 3,5 & 38640 & 4,8 & 93989 & 11,1 & 96585 & 11,2 & 129791 & 14,2 & 129804 & 13,9 \\
\hline ES & 5000 & 5,1 & 4693 & 4,8 & 1138 & 0,7 & 3534 & 1,7 & 5430 & 2,5 & 9565 & 4,3 & 9915 & 4,3 & 17289 & 7,1 & 17305 & 7 \\
\hline$M G$ & 30000 & 4,4 & 23387 & 3,4 & 70000 & 6,9 & 26656 & 2,2 & 50849 & 4 & 85250 & 6,4 & 86402 & 6,5 & 125562 & 8,9 & 125712 & 8,9 \\
\hline RJ & 32000 & 5,2 & 30890 & 5 & 55000 & 6,3 & 10265 & 1 & 31142 & 3 & 64962 & 6,2 & 65766 & 6,1 & 116872 & 10,4 & 117305 & 10,3 \\
\hline SP & 64064 & 4,9 & 3626 & 7,1 & 200000 & 10,1 & 47351 & 1,9 & 78789 & 3,1 & 194459 & 7,2 & 196597 & 7,1 & 298653 & 10,2 & 299305 & 10,1 \\
\hline SE & 131064 & 4,8 & 152596 & 5,6 & 326138 & 8,1 & 87806 & 1,8 & 166210 & 3,3 & 354236 & 6,7 & 358680 & 6,6 & 558376 & 9,8 & 559627 & 9,7 \\
\hline PR & 7000 & 1,7 & 2215 & 2,9 & 3068 & 0,6 & 10338 & 1,6 & 27185 & 4,1 & 51066 & 7,4 & 51656 & 7,4 & 5501 & 9 & 65620 & 8,9 \\
\hline RS & 20000 & 4,6 & 19529 & 4,5 & 51297 & 8,5 & 29754 & 4,2 & 55820 & 7,6 & 80713 & 10,7 & 81320 & 10,7 & 114304 & 14,4 & 114499 & 14,4 \\
\hline SC & 5072 & 2,4 & 6870 & 3,2 & 15551 & 5,2 & 7955 & 2,2 & 16969 & 4,4 & 29915 & 7,5 & 30390 & 7,5 & 41521 & 9,5 & 41686 & 9,5 \\
\hline$s$ & 32072 & 0 & 38614 & 3,6 & 69916 & 4,8 & 48047 & 2,8 & 99974 & 5,6 & 161694 & 8,7 & & 8,7 & 221326 & 11,3 & 221805 & 11,2 \\
\hline Total & 210930 & 3,6 & 260027 & 4,4 & 533456 & 5,9 & 227461 & 2,1 & 419941 & 3,6 & 840108 & 6,9 & 864273 & 7 & 1387682 & 10,6 & 1390821 & 10,5 \\
\hline
\end{tabular}

Fontes: Boletim Nacional do PT e Secretaria de Organização (Sorg) do PT. 
Tabela 2

Capilaridade organizativa do PT (2003-2009), por UF

\begin{tabular}{|c|c|c|c|c|c|c|c|c|c|c|c|c|c|c|c|}
\hline & \multicolumn{5}{|c|}{2003} & \multicolumn{5}{|c|}{2005} & \multicolumn{5}{|c|}{2009} \\
\hline & Mun. & DMs & $\%$ DMs & CPMs & $\%$ PT Org & Mun. & DMs & $\%$ DMs & CPMs & $\%$ PT Org & Mun. & DMs & $\%$ DMs & CPMs & $\%$ PT Org \\
\hline$A C$ & 22 & 19 & 86,4 & 3 & 100 & 22 & 19 & 86,4 & 3 & 100 & 22 & 21 & 95,4 & 1 & 100 \\
\hline$A M$ & 62 & 36 & 58,1 & 15 & 82,3 & 62 & 38 & 61,3 & 24 & 100 & 62 & 56 & 90,3 & 2 & 93,5 \\
\hline$A P$ & 16 & 14 & 87,5 & 1 & 93,8 & 16 & 13 & 81,2 & 3 & 100 & 16 & 15 & 93,7 & 1 & 100 \\
\hline PA & 143 & 91 & 63,6 & 46 & 95,8 & 143 & 91 & 63,3 & 52 & 100 & 143 & 134 & 93,7 & 9 & 100 \\
\hline RO & 52 & 41 & 78,8 & 11 & 100 & 52 & 41 & 78,8 & 11 & 100 & 52 & 45 & 86,5 & 6 & 98,1 \\
\hline RR & 15 & 5 & 33,3 & 2 & 46,7 & 15 & 5 & 33,3 & 10 & 100 & 15 & 13 & 86,7 & 2 & 100 \\
\hline TO & 139 & 42 & 30,2 & 66 & 77,7 & 139 & 42 & 30,2 & 79 & 87 & 139 & 76 & 54,7 & 60 & 97,8 \\
\hline Norte & 449 & 248 & 55,2 & 144 & 87,3 & 449 & 249 & 55,4 & 182 & 96 & 449 & 360 & 80,2 & 81 & 98,2 \\
\hline$A L$ & 102 & 44 & 43,1 & 4 & 47,1 & 102 & 44 & 43,1 & 49 & 91,2 & 102 & 63 & 61,8 & 35 & 96,1 \\
\hline$B A$ & 417 & 190 & 45,6 & 170 & 86,3 & 417 & 190 & 45,6 & 170 & 86,3 & 417 & 333 & 79,9 & 82 & 99,5 \\
\hline CE & 184 & 112 & 60,9 & 46 & 85,9 & 184 & 110 & 59,8 & 73 & 99,4 & 184 & 149 & 81 & 29 & 96,7 \\
\hline MA & 217 & 76 & 35 & 67 & 65,9 & 217 & 76 & 35 & 67 & 65,9 & 217 & 150 & 69,1 & 48 & 91,2 \\
\hline PB & 223 & 81 & 36,3 & 56 & 61,4 & 223 & 81 & 36,3 & 112 & 86,5 & 223 & 148 & 66,4 & 46 & 87 \\
\hline PE & 184 & 100 & 54,1 & 36 & 73,5 & 184 & 100 & 54,3 & 37 & 74,4 & 184 & 149 & 81 & 34 & 99,4 \\
\hline $\mathrm{Pl}$ & 224 & 117 & 52,5 & 55 & 77,1 & 224 & 118 & 52,7 & 99 & 96,9 & 224 & 193 & 86,2 & 29 & 99,1 \\
\hline RN & 167 & 43 & 25,7 & 42 & 50,9 & 167 & 43 & 25,7 & 101 & 86,2 & 167 & 95 & 56,9 & 40 & 80,8 \\
\hline SE & 75 & 47 & 62,7 & 17 & 85,3 & 75 & 47 & 62,7 & 25 & 96 & 75 & 74 & 98,7 & 1 & 100 \\
\hline Nordeste & 1793 & 810 & 45,2 & 493 & 72,7 & 1793 & 809 & 45,1 & 733 & 90,6 & 1793 & 1354 & 75,5 & 344 & 94,7 \\
\hline GO & 246 & 171 & 69,5 & 60 & 93,9 & 246 & 172 & 69,9 & 74 & 100 & 246 & 160 & 65 & 86 & 100 \\
\hline MS & 77 & 70 & 90,9 & 7 & 100 & 78 & 69 & 88,5 & 8 & 98,7 & 78 & 74 & 94,9 & 4 & 100 \\
\hline MT & 142 & 70 & 49,3 & 38 & 76,1 & 141 & 67 & 47,5 & 70 & 97,2 & 141 & 132 & 93,6 & 7 & 98,6 \\
\hline Centro & 465 & 311 & 66,9 & 105 & 89,5 & 465 & 308 & 66,2 & 152 & 98,9 & 465 & 366 & 78,7 & 97 & 99,6 \\
\hline
\end{tabular}


OPINIÃO PÚBLICA, Campinas, vol. 17, no 1, Junho, 2011, p.01-44

\begin{tabular}{|l|r|r|r|r|r|r|r|r|r|r|r|r|r|r|r|}
\hline ES & 78 & 50 & 64,1 & 24 & 94,9 & 78 & 49 & 62,8 & 29 & 100 & 78 & 57 & 73,1 & 20 & 98,7 \\
\hline MG & 853 & 435 & 51 & 279 & 83,7 & 853 & 417 & 48,9 & 410 & 96,9 & 853 & 737 & 86,4 & 65 & 94 \\
\hline RJ & 92 & 62 & 67,4 & 28 & 97,8 & 92 & 62 & 67,4 & 30 & 100 & 92 & 81 & 88 & 9 & 97,8 \\
\hline SP & 645 & 328 & 50,9 & 244 & 88,7 & 645 & 313 & 48,5 & 311 & 96,7 & 645 & 457 & 70,8 & 165 & 96,4 \\
\hline Sudeste & $\mathbf{1 6 6 8}$ & $\mathbf{8 7 5}$ & $\mathbf{5 2 , 4}$ & $\mathbf{5 7 5}$ & $\mathbf{8 6 , 9}$ & $\mathbf{1 6 6 8}$ & $\mathbf{8 4 1}$ & $\mathbf{5 0 , 4}$ & $\mathbf{7 8 0}$ & $\mathbf{9 2 , 7}$ & $\mathbf{1 6 6 8}$ & $\mathbf{1 3 3 2}$ & $\mathbf{7 9 , 8}$ & $\mathbf{2 5 9}$ & $\mathbf{9 5 , 4}$ \\
\hline PR & 399 & 184 & 46,1 & 144 & $\mathbf{8 2 , 2}$ & 399 & 183 & 45,9 & 207 & 97,7 & 399 & 235 & 58,9 & 143 & 94,7 \\
\hline RS & 497 & 361 & 72,6 & 113 & 95,4 & 496 & 359 & 72,4 & 118 & 96,2 & 496 & 375 & 75,6 & 110 & 97,8 \\
\hline SC & 293 & 168 & 57,3 & 92 & $\mathbf{8 8 , 7}$ & 293 & 171 & 58,4 & 104 & 93,8 & 293 & 217 & $\mathbf{7 4}$ & $\mathbf{7 0}$ & 97,9 \\
\hline Sul & $\mathbf{1 1 8 9}$ & $\mathbf{7 1 3}$ & $\mathbf{6 0}$ & $\mathbf{3 4 9}$ & $\mathbf{8 9 , 3}$ & $\mathbf{1 1 8 8}$ & $\mathbf{7 1 3}$ & $\mathbf{6 0}$ & $\mathbf{4 2 9}$ & $\mathbf{9 6 , 1}$ & $\mathbf{1 1 8 8}$ & $\mathbf{8 2 7}$ & $\mathbf{6 9 , 6}$ & $\mathbf{3 2 3}$ & $\mathbf{9 6 , 8}$ \\
\hline Total & $\mathbf{5 5 6 4}$ & $\mathbf{2 9 5 7}$ & $\mathbf{5 3 , 1}$ & $\mathbf{1 6 6 6}$ & $\mathbf{8 3 , 1}$ & $\mathbf{5 5 6 3}$ & $\mathbf{2 9 2 0}$ & $\mathbf{5 2 , 5}$ & $\mathbf{2 2 7 6}$ & $\mathbf{9 3 , 4}$ & $\mathbf{5 5 6 3}$ & $\mathbf{4 2 3 9}$ & $\mathbf{7 6 , 2}$ & $\mathbf{1 1 0 4}$ & $\mathbf{9 6}$ \\
\hline
\end{tabular}

Fonte: Secretaria de Organização (Sorg) do PT. 


\section{Gráfico 1}

Porcentagem de filiados ao PT e eleitores (1981-2010), por região

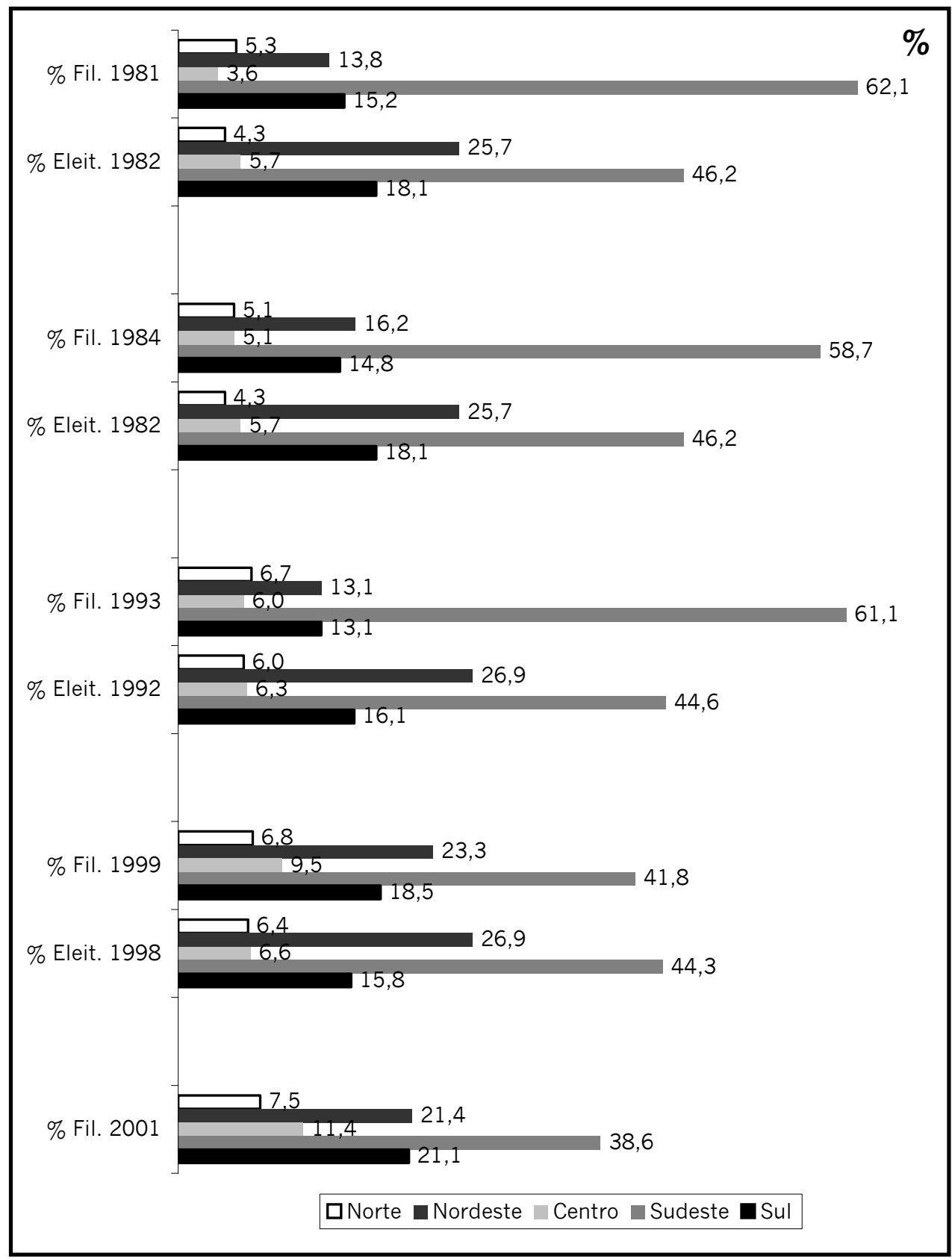

Fontes: Secretaria de Organização (Sorg) do PT e Tribunal Superior Eleitoral (TSE). 


\section{Gráfico 2}

Porcentagem de filiados ao PT e eleitores nas capitais e cidades com mais de 200 mil eleitores (G-80) (2004-2008)

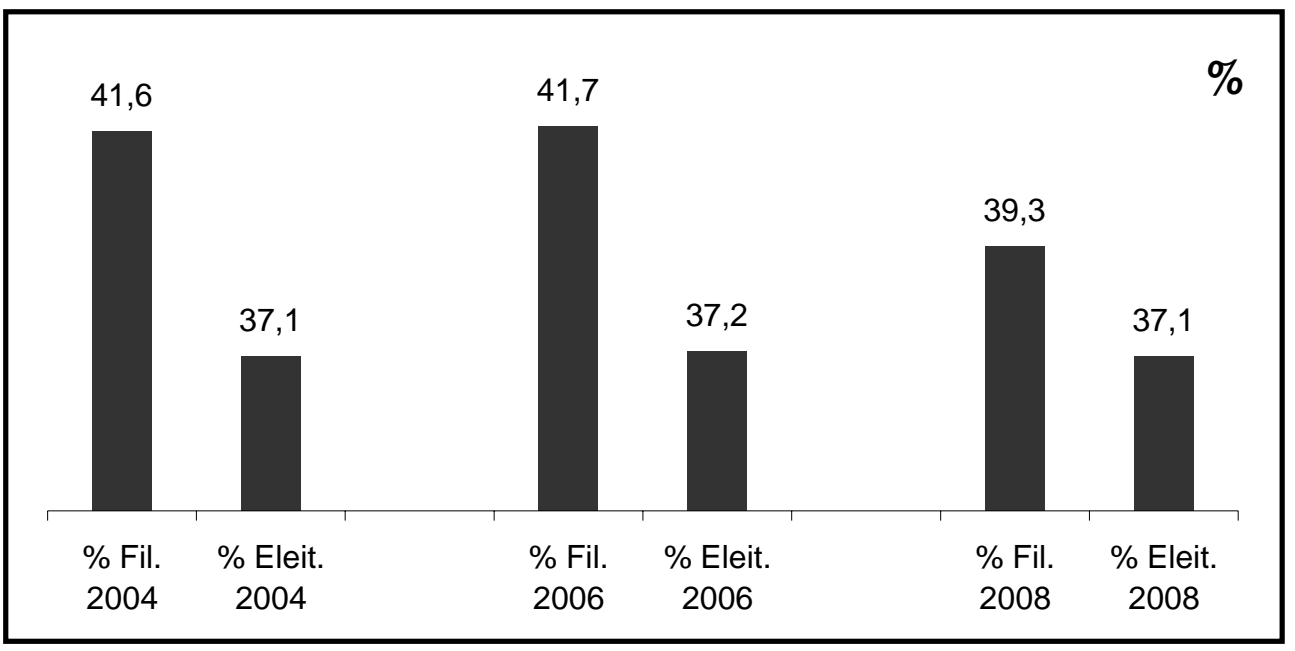

Fontes: Secretaria de Organização (Sorg) do PT e TSE.

A relação entre os partidos políticos e seus filiados pode ser tratada de duas maneiras: de uma perspectiva individual ou a partir de uma abordagem mais organizativa, centrada nos próprios partidos (BARTOLINI, 1983; SCARROW, 1994). É exatamente nesse lado da equação que concentramos a nossa análise. A decisão de buscar ou não uma grande base de filiados está diretamente ligada à visão dos dirigentes do partido quanto a contar ou não com muitos membros na agremiação. Baseando-se em trabalhos como os de Bartolini (1983) e Scarrow (1994), Méndez Lago (2000), ao analisar a estratégia organizativa do Partido Socialista Operário Espanhol (PSOE), buscou sistematizar os custos e benefícios, tanto internos quanto externos, na adoção, por parte dos líderes partidários, de uma estratégia organizativa que privilegie a incorporação de um grande contingente de filiados. Com algumas alterações, seguimos aqui a sua sistematização, lembrando que ela vale para partidos que operam em ambientes democráticos:

Custos:

a) Instabilidade interna. Um grande contingente de membros, fruto de uma política ampla de filiação, pode resultar em uma maior dificuldade dos líderes para controlar o partido ou ameaçar a coesão interna, especialmente se a agremiação dispuser de mecanismos amplos de participação na tomada de decisões. 
b) Riscos eleitorais. A base partidária pode defender propostas políticas que distanciem o partido do eleitor médio, ampliando o risco de derrota em eleições e dificultando a alteração do programa partidário;

c) Desperdício de recursos. A arregimentação e a manutenção de um grande número de filiados obrigam o partido a alocar recursos financeiros, de pessoal e organizativos para esses fins.

Benefícios:

a) Ampliação do poder interno. Os filiados podem servir para as faç̧ões internas aumentarem seu poder nas estruturas decisórias da agremiação;

b) Mão de obra voluntária. Um grande contingente de membros pode facilitar o recrutamento de voluntários para realizar uma série de tarefas importantes, especialmente durante o período de campanhas eleitorais;

c) Recrutamento de candidatos. Os filiados podem transformar-se em candidatos a cargos eletivos ou preencher postos em administrações controladas pelo partido;

d) Força política. Um expressivo número de membros pode demonstrar que o partido conta com grande aceitação e penetração junto ao eleitorado;

e) Recursos financeiros. Os filiados, por meio de contribuições previstas pelos partidos, podem significar uma importante fonte de recursos financeiros;

f) Desenvolvimento de políticas. Os filiados, por meio de suas experiências e vinculações com diferentes setores da sociedade, como movimentos sociais, empresários e universidades, podem auxiliar no desenvolvimento de políticas por parte dos partidos (MÉNDEZ LAGO, 2000, p. 158-161; HEIDAR, 2006, p. 304; WARE, 1996, p. 63-64).

A análise da relação entre os custos e os benefícios de contar com uma ampla base de filiados por parte de dirigentes partidários pode variar ao longo do tempo e de acordo tanto com o contexto interno quanto com o ambiente social e institucional em que a agremiação está inserida. Além disso, a decisão de contar com muitos membros pode não se efetivar se o partido não dispuser de recursos e organização para obtê-los, ou não conseguir atrair os filiados por meios dos incentivos disponibilizados. Dessa forma, desvendar as razões da variação no número de filiados de um partido requer a combinação de três planos de análise: a) 
as ações do partido no sentido de ampliar a sua base; b) a avaliação da capacidade organizativa da agremiação; e c) a análise do quadro político mais amplo no qual o partido está inserido.

O PT sempre se preocupou com a construção de um partido de massas e buscou, em diferentes momentos da sua história, incrementar o número de filiados. Até 2001 , os mecanismos privilegiados para a aquisição de novos membros foram as campanhas de filiação. Além do esforço de filiação inicial, no começo dos anos 1980, o PT organizou campanhas para atrair novos membros em 1987, 1992 e 1995. É difícil avaliar o sucesso dessas campanhas pela escassez de dados confiáveis. No entanto, ao combinarmos a análise dos dados disponíveis com a avaliação feita pelo próprio PT ou por membros do partido, é possível caracterizá. las como de sucesso parcial, especialmente se comparadas com as campanhas de 2003 e 2006. Em que pese a provável superestimação dos dados relativos aos filiados nos anos 1980 e 1990, o partido saltou de cerca de 260 mil filiados, em 1984, para pouco mais de 455 mil em 1988. Analisando a taxa de FPME, o avanço foi de 4,4 para 6,0 (36,4\%) (RIBEIRO, 2008, p. 245). Embora não consigamos mensurar exatamente o efeito da campanha de 1987 sobre esse crescimento, é possível supor que ele tenha sido positivo. Já a campanha realizada cinco anos mais tarde não atingiu seus objetivos: coordenada pelo DN, buscou mobilizar os Diretórios Estaduais e Municipais para atingir a marca de 1 milhão de filiados até o final daquele ano. Em 1993, porém, o PT contabilizava 533 mil filiados e o índice de FPME permanecia praticamente o mesmo de 1988 (5,9). Ao analisar a campanha de 1987 e as perspectivas para a de 1992, Jorge Almeida, então Secretário Nacional de Juventude e membro do DN, observou que o partido não possuía recursos financeiros e organizativos para conduzir tal processo, que, na visão do autor, levaria, no máximo, a um aumento no número de filiados, sem que estes fossem localizáveis ou integrassem a dinâmica partidária (1992). O PT, ao lançar a campanha de 1995, reconheceu os problemas organizativos da agremiação e a necessidade de reorientar o processo de filiação para a manutenção de um cadastro atualizado e permanente dos membros do partido como forma de facilitar a mobilização e a comunicação internas, como é possível ver no texto de Tatau Godinho, secretária de organização à época:

"Há vários anos se discute a necessidade de empreendermos uma grande reestruturação organizativa no partido. [...] Embora já tenhamos feito algumas campanhas de recadastramento de filiados do PT, nenhuma delas resultou em uma atualização efetiva do quadro de filiados ao partido.

É um consenso entre nós a importância do partido manter uma relação permanente com seus filiados. Um partido de massas como o PT precisa de filiados localizáveis (1995, s.p.). 
Apesar do diagnóstico, o resultado da campanha organizada em 1995 não foi muito diferente dos anteriores. O partido continuava sem contar com um cadastro organizado e parecia não conseguir expandir sua base de filiados significativamente em função de seu esforço de filiação. Alguns meses após a decisão de lançamento da campanha, o partido observou, no seu $10^{\circ} \mathrm{EN}$, que seria necessário retomar o processo de filiação e recadastramento articulando-o com a expansão do partido para os municípios em que não possuía diretório, em um claro sinal de reconhecimento da ineficiência do processo de captação de membros (PT, 1998, p. 637).

As observações de Almeida (1992), Godinho (1995) e do próprio PT (1998) são ótimos pontos de partida para avaliarmos os resultados da ampliação da base de filiados petista durante os anos 1980 e 1990. Primeiro, é necessário ponderar que, apesar das derrotas nas eleições presidenciais de 1989, 1994 e 1998, o PT recebeu sempre mais de $10 \%$ dos votos para a Câmara dos Deputados nas eleições de 1990 (10,2\%), $1994(13,1 \%)$ e 1998 (13,2\%) e foi apontado como o partido preferido por mais de $10 \%$ dos brasileiros durante toda a década (SAMUELS, 2008a, p. 305), demonstrando que havia espaço de crescimento para além do 0,59\% dos eleitores filiados à agremiação em 1993, ou mesmo para além dos 700 mil petistas "históricos" (0,74\% do eleitorado) que o partido estimava ter em 1995 (PT, 1998, p. 637) ${ }^{6}$. Segundo, a liderança partidária sempre considerou um ativo importante contar com um amplo número de filiados e agiu, por meio de seguidas campanhas nacionais, para incrementar esse número. Dessa forma, está no plano da capacidade organizacional a resposta para o sucesso apenas parcial na captação de filiados no período. Apesar de contar com uma proposta política com boa receptividade junto ao eleitorado, as ações do partido no sentido de ampliar seu número de membros esbarraram na falta de recursos financeiros, capilaridade organizativa, coordenação das ações e medidas institucionais adicionais para o maior incentivo à entrada de novos membros.

As barreiras institucionais e organizativas para a expansão do PT começaram a ser removidas a partir de 1995, quando os moderados retomaram o comando do partido no $10^{\circ} \mathrm{EN}$. Tenso e muito disputado, esse Encontro marcou o início da aliança entre as tendências internas Articulação e Democracia Radical, que seria a espinha dorsal do grupo que controlaria o partido por dez anos e ficaria conhecido como Campo Majoritário. Com José Dirceu à frente da presidência do partido e com as facções moderadas controlando os cargos diretivos mais importantes, o PT dava início a um amplo processo de remodelagem na sua organização, desenho institucional e ideologia, com consequências não só no âmbito da participação na política institucional, mas também na sua relação mais

\footnotetext{
${ }^{6}$ São considerados petistas "históricos" aqueles que em algum momento da vida do PT foram filiados ao partido.
} 
ampla com a sociedade. Sinais das mudanças no aspecto organizativo apareceram na resolução sobre Construção Partidária aprovada no $10^{\circ} \mathrm{EN}$, derivada da teseguia apresentada pela Articulação. Sobre as finanças partidárias, o documento afirmou o seguinte:

“[...] É uma realidade a fragilidade de nossa política de finanças, voluntarista, esporádica, sem continuidade, sem planejamento e controle e, muitas vezes, confundindo politização com amadorismo, numa atividade que precisa ser profissional ao extremo.

[...] Chegou a hora de o PT ousar na área financeira. Na situação atual, a falta de recursos inviabiliza uma política de finanças, deixando de lado um potencial de mais de 500 mil filiados, inviabilizando a comunicação política com eles, marginalizando-os das atividades partidárias, impedindo que contribuam para a definição de nossas políticas" (PT, 1998, p. 636-637).

Mais adiante, no mesmo documento, o PT reconheceu a necessidade de ampliar a sua capilaridade organizativa, com a abertura de diretórios e a realização de atividades partidárias, como encontros e seminários, em diversas regiões do país (PT, 1998, p. 637).

No aspecto financeiro, a resolução aprovada no $10^{\circ} \mathrm{EN}$ prenunciava algumas das transformações pelas quais o partido passaria nos anos seguintes. Parecia claro aos líderes que assumiram o partido em 1995 que a agremiação necessitava de mais recursos e um melhor gerenciamento de seu orçamento para ampliar sua presença no interior do país e tornar-se mais competitiva eleitoralmente, e que havia um crescente descompasso entre os objetivos partidários e a forma em que a estrutura organizativa estava configurada. Diante disso, como mostra Ribeiro (2008), o partido passou por uma reestruturação na sua organização financeira a partir da segunda metade dos anos 1990, com uma crescente centralização de recursos no DN. Essa reestruturação foi facilitada pelas alterações na legislação sobre partidos políticos (Lei 9096/95), que elevou consideravelmente a quantidade de recursos disponíveis aos partidos por meio do fundo partidário. Segundo dados organizados pelo autor, o partido praticamente triplicou suas receitas entre 1995 e 1996, e o fundo partidário passou a ser a principal fonte de renda do PT (2008, p. 108-110). A crescente participação institucional do partido também resultou em um aumento de recursos provenientes de contribuições estatutárias previstas para todos os filiados que ocupassem cargos eletivos ou comissionados. Em 2001, essas contribuições passaram a ser arrecadadas e distribuídas pela Secretaria Nacional de Finanças, em um claro esforço para garantir o aporte permanente de recursos provenientes dessa fonte e evitar os atrasos nos repasses por parte dos diretórios 
subnacionais (PT, 2001b, p. 47). A partir do ano 2000, a moderação ideológica do partido e o esforço de aproximação a setores do empresariado começaram a render benefícios financeiros ao PT e o número de doações de empresas quadruplicou entre 2000 e 2004. Construtoras, empresas de coleta de lixo, bancos e grandes indústrias de transformação passaram a figurar entre os contribuintes do partido (RIBEIRO, 2008, p. 111).

Paralelamente à reorganização no âmbito financeiro, o partido também concentrou esforços para ampliar a sua penetração territorial e se tornar, efetivamente, um partido presente em todo o país, como mostra a Tabela 2. Mesmo depois de uma campanha presidencial em que quase venceu, em 1989, o partido, quatro anos mais tarde, encontrava-se organizado em apenas $44 \%$ dos municípios brasileiros, sendo que o número era ainda mais baixo nas regiões Norte (34\%), Nordeste (37\%) e Centro-Oeste (37\%). Em 2000, é possível notarmos que o quadro se alterara substancialmente e que o PT estava presente em $74 \%$ dos municípios, e apenas a região Nordeste apresentava números abaixo da média nacional (62\%). Em 2001, o partido reafirmou sua preocupação com a expansão organizativa e decidiu, no $11^{\circ} \mathrm{EN}$, atingir a marca de 3,5 mil DMs no ano seguinte (PT, 2001b, p. 45). Embora a meta não tenha sido atingida no prazo especificado, em 2003 o partido já contava com algum tipo de organização, somando as CPMs e os DMs, em $83,1 \%$ das cidades brasileiras. Esse esforço continuaria nos anos seguintes, com a abertura significativa de CPMs entre 2003 e 2005, que saltaram de 1666 para 2276 no período, e a posterior consolidação de boa parte delas em DMs no período entre 2005 e 2009. Ao final da sua terceira década de existência, o PT possuía DMs em $76,2 \%$ dos municípios brasileiros e CPMs em mais 19,8\%, totalizando uma presença organizativa em $96 \%$ das cidades do país.

Acreditamos que a reestruturação organizativa do partido iniciada na segunda metade da década de 1990 tenha sido fundamental para a expansão da base de filiados a partir de 2003. Com mais recursos financeiros e uma maior presença no interior do país, ficou mais fácil atrair filiados - além de participar de mais pleitos e eleger mais representantes no nível local. No entanto, outras ações do partido contribuíram para esse crescimento. Méndez Lago, na sua análise sobre o PSOE, avalia que a atuação partidária em três dimensões (Inclusão, Compromisso e Participação) é essencial para a captação de novos membros. A primeira trata das barreiras para a entrada de um simpatizante no partido. Campanhas de filiação, ampliação da presença organizativa e facilidade no processo de registro dos novos membros são alguns dos indicadores utilizados para compreender as ações do partido nessa dimensão. A segunda diz respeito às oportunidades de participação do filiado nas atividades partidárias. Ações fora do período eleitoral e uma estrutura que organize os filiados indicam uma preocupação com a atração e a inclusão de novos membros na dinâmica da agremiação. A terceira dimensão está relacionada 
aos canais de participação disponíveis aos filiados no processo interno de tomada de decisão, especialmente no que se refere à seleção de candidatos e à escolha dos dirigentes partidários (2000, p. 162-163).

É na primeira dimensão, a da Inclusão, que encontramos a maior preocupação do partido a partir da segunda metade da década de 1990. Além da preocupação com a construção de um cadastro nacional, que permitiria ao PT conhecer suas debilidades organizativas e construir uma política de filiação mais racional e focada nas localidades em que o partido se encontrava mais fraco, a agremiação mostrou uma preocupação em facilitar o processo de entrada de novos membros, alterando as regras de filiação (PT, 1999, p. 27). Em 2001, após anos de discussão, o novo Estatuto do PT foi aprovado e, nele, o partido instituiu, no Art. 10, a possibilidade de filiações coletivas durante a realização de campanhas de adesão (PT, 2001a, p. 21).

Após os resultados das eleições de 2002, nas quais o partido elegeu o presidente da República e foi o que mais votos recebeu tanto para as Assembleias Legislativas quanto para a Câmara dos Deputados, a direção do PT concluiu que havia espaço para uma ampla campanha de filiação em 2003. Com os slogans "Coloque nossa estrela no lugar certo: no coração de um amigo" e "Se você é PT de coração, queremos falar com você" (SORG, 2003, s.p.), a campanha iniciada em setembro de 2003 foi muito mais organizada e estruturada do que as anteriores. 0 partido disponibilizou um número gratuito 0800 e um espaço especial em seu sítio na internet para aqueles que quisessem obter informações. Os dados obtidos pelo telefone e pela internet eram repassados aos diretórios locais para que estes entrassem em contato diretamente com os interessados. Os diretórios receberam material gráfico sobre o PT, brindes para distribuir aos novos membros e um manual no qual havia uma série de medidas que deveriam adotar para que a campanha fosse bem-sucedida, como o estabelecimento de uma equipe de filiação, um horário fixo de atendimento e recomendações a respeito de como tratar os interessados em ingressar no partido (SORG, 2003, s.p.).

Embora seja impossível mensurar exatamente o efeito da campanha na captação de filiados, os dados nos mostram que ela foi bem-sucedida. 0 partido saltou de cerca de 420 mil filiados, em junho de 2003, para mais de 800 mil, em janeiro de 2005. Na avaliação do número de filiados por eleitor, o PT passou de 3,6 para 6,9 FPME e todos os estados apresentaram um crescimento significativo no número de membros no período (Tabela 1 ).

Em abril de 2006, ao final de seu $13^{\circ}$ EN, o PT lançou uma nova campanha de filiação. Em um contexto diferente, marcado pela crise de corrupção que atingiu o partido e muitas das suas lideranças em 2005/2006, essa campanha buscou também recuperar a imagem do PT junto aos seus simpatizantes e sinalizar aos filiados que a agremiação estava recuperada dos escândalos políticos e pronta para 
disputar as eleições de 2006. No guia elaborado para a campanha, o partido afirmou não se preocupar tanto com prazos e metas de filiação - embora achasse possível superar a marca de 1 milhão de filiados -, mas sim em preparar os militantes petistas para a disputa eleitoral e ampliar a presença do partido nos pequenos municípios (SORG, 2006, p. 3). Do ponto de vista organizativo, a novidade dessa campanha foi a possibilidade de contar com dados detalhados a respeito do número de membros do partido em cada UF e município. O sistema montado pela Secretaria de Organização do PT (Sorg) tornou possível fazer um diagnóstico preciso da situação organizativa do partido em cada estado e orientar as ações dos diretórios locais.

A julgar pelo crescimento no número de filiados, a campanha de 2006 também foi bem-sucedida. Em janeiro de 2008, o partido contava com quase 1,4 milhão de filiados e um índice de 10,6 FPME, o que significava que, pela primeira vez na sua história, o partido conseguia superar a marca de $1 \%$ de eleitores filiados. Essa segunda onda de expansão de filiados no governo Lula, como mencionamos antes, também foi marcada por um forte crescimento do partido na região Nordeste, que saltou de 5,5 para 10,2 FPME (Tabela 1), e por uma ampliação na proporção do número de filiados em municípios de pequeno e médio porte (Gráfico 2).

Além das campanhas de filiação, outra importante redução na barreira de inclusão foi a maior presença territorial do PT. A expansão rumo aos pequenos municípios tornou mais fácil o processo de captação de membros, além de potencializar os efeitos das campanhas nacionais. Um indicativo da ligação entre a capilaridade organizativa e a presença de filiados ao partido aparece na Tabela 3, na qual encontramos uma associação significativa, positiva e moderada entre a porcentagem de municípios no qual o PT estava organizado, por estado, e a taxa de FPME. No entanto, é preciso observar os dados com cuidado, pois a queda as correlação a partir de 2003 indica que as variáveis estiveram menos ligadas durante as ondas de expansão dos filiados no governo Lula, indicando uma menor associação entre a penetração territorial do partido e a taxa de FPME. 
OPINIÃO PÚBLICA, Campinas, vol. 17, no 1, Junho, 2011, p.01-44

Tabela 3

Correlação entre a taxa de FPME e a porcentagem de DMs organizados, por UF ( $r$ de Spearman)

\begin{tabular}{|c|c|c|c|}
\hline & \multicolumn{3}{|c|}{ DMs Organizados (\%) } \\
\hline $\begin{array}{c}\text { Filiados por Mil Eleitores } \\
\text { (FPME) }\end{array}$ & $\mathbf{2 0 0 3}$ & $\mathbf{2 0 0 5}$ & $\mathbf{2 0 0 9}$ \\
\cline { 2 - 4 } &, $556^{* * *}$ &, $454^{* *}$ &, $477^{* *}$ \\
\hline
\end{tabular}

Fonte: Sorg do PT. Sig: *** $p<0,01 ;{ }^{* *} p<0,05 . N=26$ (O DF foi excluído por contar com apenas um DM).

Ainda que indiretamente, outros dois aspectos importantes parecem ter facilitado a entrada de novos membros no partido a partir de 2003 e se enquadrariam na dimensão da Inclusão. Chamamos esses dois aspectos de: a) "redução das barreiras ideológicas" e b) "efeito Lula". Embora não seja possível mensurar o posicionamento ideológico dos filiados - especialmente daqueles que entraram no partido a partir de 2003, é possível supor que a moderação ideológica do PT a partir da segunda metade da década de 1990 e a caminhada rumo ao centro do espectro político, amplamente discutida na literatura (AMARAL, 2003; SAMUELS, 2004; HUNTER, 2007; 2008b; 2010; RIBEIRO, 2008), tenham exercido algum efeito positivo na captação de filiados durante o governo Lula. Mais perto do centro, o partido ampliou o seu "território de caça", aproximando-se de um grande contingente de eleitores que não se identificavam com posturas mais radicais de esquerda. Alguns indícios desse fenômeno encontram-se no trabalho de Samuels (2008a). Ao analisar os eleitores identificados com o partido em 2007, o autor mostra que, diferentemente do que acontecia em 2002, "a ideologia de esquerda não prediz mais a identificação com o PT" (2008a, p. 311). Samuels sugere também que o crescimento da identificação com o partido nos últimos anos, de cerca de 10\%, em 1997, para um nível próximo aos 20\%, a partir de 2001, está relacionado à moderação ideológica da agremiação. Identificar-se com um partido e filiar-se a ele são coisas muito diferentes. No entanto, parece-nos razoável afirmar que a ampliação do número de eleitores identificados com o PT facilita o trabalho do partido no processo de recrutamento de novos membros.

O "efeito Lula", também de difícil mensuração, é a associação entre a popularidade do presidente e seu governo e o crescimento no número de filiados ao PT, especialmente a partir de 2006. O primeiro indicador que podemos é o crescimento, entre 2006 e 2008, na taxa de FPME muito acima da média nacional na região Nordeste. Nesse período, o aumento na taxa foi de $85,4 \%$ na região, enquanto no Brasil foi de 51,4\%. Como mostra o Gráfico 3, a diferença entre os níveis de aprovação do governo Lula no Nordeste e no Brasil aumentou em 2006, com a aprovação da administração Lula atingindo $68 \%$ na região. Nesse mesmo 
ano, essa foi a região em que Lula recebeu a maior porcentagem de votos válidos $(66,8 \%)$ no primeiro turno da sua campanha pela reeleição, representando um crescimento de 20,9 pontos percentuais com relação às eleições de 2002. Por sua vez, o PT obteve os mesmos 13,2\% dos votos para a Câmara dos Deputados na região nos pleitos realizados em 2002 e 2006.

O segundo indicador é a análise do grau de associação entre a variação na taxa de FPME (em \%), por UF, entre 2006 e 2008, e a porcentagem de votos válidos recebidos pelo presidente Lula no primeiro turno em 2006. Como forma de controle, avaliamos também se houve associação entre a variação nas taxas de FPME entre 2006 e 2008, por estado, e a porcentagem de votos recebidos pelo PT para a Câmara dos Deputados em 2006, e replicamos os testes com a variação da taxa de FPME entre 2003 e 2006, por UF, e as porcentagens de votos válidos recebidos por Lula no primeiro turno das eleições presidenciais de 2002, e pelo PT para a Câmara no mesmo ano (Tabela 4).

\section{Gráfico 3}

\section{Aprovação do governo Lula (\%) (2003-2010)}

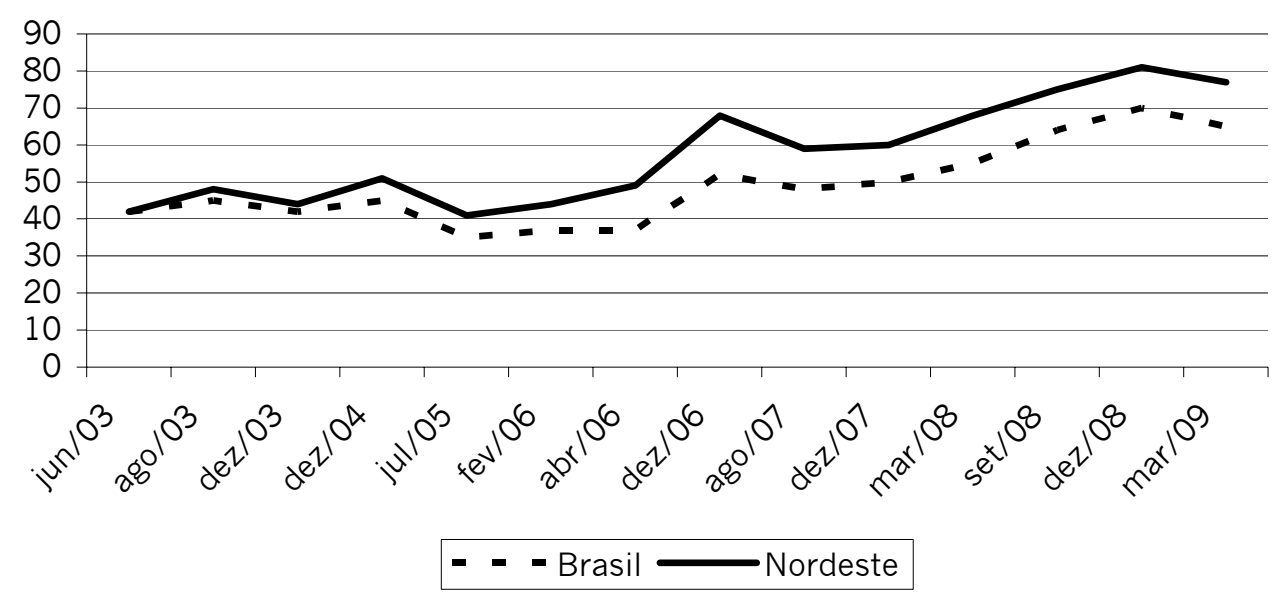

Fonte: Instituto Datafolha (indicam a porcentagem de pessoas que responderam "ótimo" e "bom" para a seguinte pergunta: "Na sua opinião o presidente Lula está fazendo um governo: disponíveis em: <http://www.datafolha.com.br>. Acesso em: 20 de fevereiro de 2010. ".). Dados 
OPINIÃO PÚBLICA, Campinas, vol. 17, no 1, Junho, 2011, p.01-44

Tabela 4

Correlação entre a variação na taxa de FPME (\%) e as votações recebidas por Lula e pelo PT (\%), por UF

\begin{tabular}{|l|l|l|l|l|}
\hline & Lula 2002 & PT 2002 & Lula 2006 & PT 2006 \\
\hline FPME 03-06 &,- 032 &,- 089 &, 035 &,- 006 \\
\hline FPME 06-08 & & &, $669^{* * * *}$ &,- 044 \\
\hline
\end{tabular}

Fontes: Sorg do PT e TSE. Sig: *** $p<0,01 . N=27$.

Os testes mostram que a correlação entre a variação na taxa de FPME entre 2006 e 2008 e a porcentagem de votos recebida pelo presidente Lula em 2006 é moderada e positiva, além de significativa. Nenhuma das outras correlações analisadas mostrou-se significativa $(p<0,1)$. Os indicadores utilizados sugerem que o PT na segunda onda de filiações durante o governo Lula encontrou mais facilidade em atrair membros na região em que o presidente gozou de grande aprovação a partir de 2006 e nos estados em que foi mais bem votado no primeiro turno das eleições daquele ano, e não naqueles em que o partido foi mais forte nas eleições para a Câmara dos Deputados. Ou seja, as barreiras de inclusão de novos filiados foram menores nos estados em que o presidente obteve seus melhores desempenhos eleitorais. Essa conclusão indica uma novidade importante no padrão de recrutamento de filiados ao partido e nas implicações políticas da alta popularidade obtida pelo presidente Lula durante o exercício de seu segundo mandato. A elas voltaremos na conclusão deste artigo.

As dimensões do Compromisso e da Participação podem ser tratadas em conjunto no caso do PT. Em ambas, é possível observarmos alterações no desenho institucional do partido voltadas para a redução nos custos de participação do filiado tanto nas atividades partidárias quanto no processo interno de tomada de decisão. A alteração do Estatuto do PT, em 2001, foi o momento de consolidação de uma série de mudanças no arranjo institucional petista que vinham sendo discutidas durante toda a década de 1990. Entre as alterações estavam novas regras para a participação dos filiados na vida partidária. A mais importante delas foi a definição da eleição direta (PED) para a escolha dos dirigentes petistas. Até 2001, os dirigentes eram escolhidos nos Encontros realizados pelo partido em todos os seus níveis. Ou seja, os filiados podiam participar diretamente apenas da escolha da direção e do presidente no nível municipal, ou zonal, dependendo do porte da cidade. Os Encontros Municipais eram os responsáveis por enviar os delegados para os Encontros Estaduais, que escolhiam o Diretório e o presidente do partido, e mandavam representantes para o Encontro Nacional, responsável por eleger o DN e o presidente nacional do PT. A estrutura decisória petista privilegiava os Encontros e estabelecia que um filiado, para participar do processo decisório nas 
instâncias superiores, necessitava passar, no mínimo, pelo crivo do Encontro em nível local. O Estatuto de 2001 mudou esse processo, fortalecendo a base de filiados ao the oferecer a possibilidade de escolher até mesmo o mais alto dirigente do partido. Isso significa que mesmo um filiado que não frequente regularmente as reuniões do partido e não compareça sempre ao diretório local pode influir no processo interno de seleção de lideranças em todos os níveis. Desde que as novas regras foram aprovadas, o PT realizou quatro PEDs, em 2001, 2005, 2007 e 2009, o que demonstra um nível elevado de atividade partidária da qual podem participar todos os filiados em períodos não eleitorais. Apenas em 2003 não ocorreram eleições no Brasil ou no PT. O nível de participação dos membros, mesmo com o aumento de filiações, manteve-se em torno de 40\%. Embora seja difícil realizar comparações temporais por conta da precariedade dos dados anteriores a 2001, Almeida afirmou, em 1992, que no máximo 20\% dos filiados participavam dos encontros do partido (1992). Além do PED, o Estatuto de 2001 definiu também quatro tipos de consulta aos membros do partido: plebiscitos, referendos, consultas e prévias eleitorais. Plebiscitos e referendos podem ser convocados em qualquer nível partidário desde que subscritos por pelo menos $20 \%$ dos filiados e possuem caráter deliberativo. As consultas seguem a mesma lógica de convocação, mas servem apenas para informar à direção a posição da base partidária sobre um tema. As prévias devem acontecer quando houver mais de um pré-candidato às eleições majoritárias. A instituição de prévias resultou na construção de mais um mecanismo importante - pois trata da seleção de candidatos - do qual podem participar todos os membros do partido independentemente de seu "nível de ativismo".

As mudanças estatutárias, defendidas pelo Campo Majoritário, resolveram, de forma engenhosa, uma difícil equação em torno da organização partidária. Ao mesmo tempo em que contemplavam as demandas internas por maior participação e democracia, ofereciam aos filiados mais mecanismos de integração às atividades partidárias, sem exigir em troca um alto nível de ativismo, fornecendo assim mais incentivos institucionais para a captação de novos membros sem comprometer a tradição do PT. Embora uma novidade no âmbito partidário brasileiro, essa prática já havia sido identificada em outros partidos localizados em democracias consolidadas e novas (SEYD, 1999; SEYD e WHITELEY, 2002; KATZ e MAIR, 2002; FREIDENBERG, 2005; SCARROW e GEZGOR, 2010; WAUTERS, 2010).

Antes de concluirmos este ponto, é necessário reportar que outros três testes de associação foram realizados para tentar elucidar um pouco mais as razões do crescimento no número de filiados ao PT a partir de 2003. Os dois primeiros buscaram medir o grau de vinculação entre o crescimento no número de filiados e o fato de o PT ser governo em um determinado período. Inicialmente, avaliamos a correlação entre o PT ser governo ou não, entre 2005 e 2009, e a 
variação (em \%) nas taxas de FPME, entre 2006 e 2008, em 392 municípios do estado de São Paulo (63\% do total de localidades em que o PT contava com algum tipo de organização em 2009). A construção dessa base de dados foi determinada pela capacidade de reunir as informações necessárias para o teste e contempla cidades em todas as regiões do estado e de diferentes portes. Os resultados encontrados indicam que praticamente não há associação entre ser governo e a variação na taxa de FPME ( $r=, 093 ; p<0,1 ; N=392)$. Como forma de limitarmos eventuais distorções regionais, replicamos o teste com os dados obtidos sobre as capitais e os municípios com mais de 200 mil eleitores no país em 2008 (G-80). Dessa maneira, avaliamos o grau de associação entre a variação na taxa de FPME (em \%) nos municípios entre 2004 e 2008 e o fato de o PT ser governo ou não entre 2005 e 2009. O teste mostra que existe uma correlação significativa, positiva e baixa entre as variáveis $(r=, 263 ; p<0,05 ; N=80)$, indicando uma associação muito sutil entre ser governo e a variação na taxa de FPME. Assim, é possível destacarmos que não há evidências concretas de que o crescimento no número de filiados ao partido nos últimos anos tenha sido fruto da disseminação de práticas clientelistas por parte de administrações municipais petistas, o que fortalece as explicações baseadas em determinantes organizativos descritas anteriormente.

O terceiro teste está relacionado à hipótese levantada por Bartolini (1983) e Méndez Lago (2000) de que a disputa interna pode levar a uma maior busca de filiados por parte das facções dos partidos. No caso petista, a hipótese foi apontada também por Ribeiro (2008, p. 279). Um dos desdobramentos possíveis dessa hipótese é a suposição de que nos locais onde a disputa interna é mais dura há incentivos para que os líderes partidários realizem filiações para fortalecer suas posições internamente, inflando o número de membros do partido. Não foi possível obter os dados das disputas estaduais e municipais do PT em todo o país e optamos por construir uma classificação categórica que divide os estados brasileiros entre aqueles em que a disputa política é forte ou fraca. Para isso, utilizamos os dados das eleições para o DN em todo o país e classificamos como estados em que há uma forte disputa política aqueles em que nenhuma chapa obteve a maioria dos votos válidos em pelo menos dois dos três PEDs realizados a partir de 2003 (BA, DF, MA, MG, MS, MT, PE, PI, RJ, RN, RS, SC e SP). Em seguida, testamos, a associação entre a variável "Disputa Política" e a variação (em \%) na taxa de FPME entre 2003 e 2010. A associação não se mostrou significativa ( $p<$ 0,1 ), indicando que a ampliação na taxa de FPME no período não esteve correlacionada com a variável "Disputa Política". No entanto, reconhecemos a necessidade de testes mais sofisticados, com um maior número de dados, para descartarmos completamente essa hipótese. 
AMARAL, O. Ainda Conectado: o PT e seus vínculos com a sociedade

\section{As lideranças do PT}

Os Encontros e Congressos Nacionais do PT são as instâncias máximas de deliberação "sobre o programa, a estratégia, a tática, a política de alianças e as linhas de construção partidária" (PT, 2001a, p. 30). Deles participam delegados de todo o país escolhidos em seus respectivos encontros estaduais. A proporcionalidade é dada de acordo com a força do partido nas UFs: até 2001, de acordo com o número de filiados, e, a partir daquela data, respeitando o número de votantes nos PEDs. Isso significa que, para um delegado chegar a um Encontro de nível nacional, ele deve passar por escolhas no nível local e estadual e ter algum tipo de inserção na máquina partidária ou projeção pública. Os dados da Tabela 5 mostram que, em todos os Congressos sobre os quais dispomos de dados, pelo menos $85 \%$ dos delegados participavam de alguma instância partidária. Na sua maioria, eram membros de instâncias municipais e estaduais de todo o país (lideranças intermediárias). Outro indicador do grau de envolvimento dos delegados na vida partidária é o número de horas dedicadas por eles ao PT: 52\% afirmaram dedicar, no $13^{\circ} \mathrm{EN}$, em 2006, mais de 40 horas por mês para atividades partidárias (DELEGADOS-PT/AUTOR, 2006). Isso permite afirmar que o conjunto de delegados compõe uma amostra representativa das lideranças da agremiação.

Tabela 5

Participação dos delegados em instâncias partidárias (\%)

\begin{tabular}{|c|c|c|c|c|c|}
\hline & $\begin{array}{l}1997 \\
\left(11^{\circ} \mathrm{EN}\right)\end{array}$ & $\begin{array}{l}1999 \\
\left(2^{\circ} \mathrm{CN}\right)\end{array}$ & $\begin{array}{l}2001 \\
\left(12^{\circ} \mathrm{EN}\right)\end{array}$ & $\begin{array}{l}2006 \\
\left(13^{\circ} \mathrm{EN}\right)\end{array}$ & $\begin{array}{l}2007 \\
\left(3^{\circ} \mathrm{CN}\right)\end{array}$ \\
\hline Participam & 87 & 89 & 91,6 & 93,1 & 89,2 \\
\hline \multicolumn{6}{|c|}{$\%$ do total de delegados } \\
\hline Núcleo de base & 7 & 10 & 8,6 & 2,5 & 2,3 \\
\hline Diretório Zonal & 6 & 8 & 7,4 & 5,2 & 7,1 \\
\hline Diretório Municipal & 47 & 47 & 43,6 & 46,6 & 52,9 \\
\hline Diretório Estadual & 43 & 43 & 43,6 & 43,9 & 29,4 \\
\hline Direção Nacional & 6 & 2 & 6,7 & 4,2 & 2,2 \\
\hline Outras & 6 & - & 10,4 & 6,5 & 3,4 \\
\hline $\mathbf{N}$ & (187) & (544) & (431) & $(864)$ & (775) \\
\hline
\end{tabular}

Fonte: Núcleo de Opinião Pública (NOP) da Fundação Perseu Abramo (FPA). 
O perfil dos delegados petistas reunido na Tabela 6 mostra importantes características da liderança do partido. A primeira delas é que, entre 1997 e 2007, houve pouca alteração no predomínio dos homens entre os delegados, evidenciando a dificuldade de inserção das mulheres na vida partidária, mesmo após a introdução de cotas para as instâncias de direção do PT a partir dos anos $1990^{7}$. Ao analisar a predominância dos homens entre a liderança petista, Ribeiro ressalta que características do ambiente partidário, que valoriza atributos identificados com o "universo simbólico masculino", e a tripla jornada a que são submetidas as militantes (no trabalho, em casa e no partido) dificultam a ascensão de mulheres na hierarquia petista (2008, p. 176-183). Com relação à idade dos delegados, há uma clara tendência de envelhecimento. Em 1997, 64\% dos delegados possuíam até 40 anos. Dez anos depois a proporção se inverteu, e apenas 35,1\% encontravam-se nessa faixa etária. Esses dados mostram a dificuldade crescente de incorporação de jovens nos quadros médios do partido e ajudam a compreender, como veremos adiante, a menor inserção do movimento estudantil entre a liderança petista ${ }^{8}$.

$O$ alto nível de escolaridade dos delegados também é uma marca do período analisado. Em nenhum dos Encontros a porcentagem de delegados que chegaram a frequentar um curso superior foi inferior a 70\%, assim como em nenhum deles foi superior a $5 \%$ a quantidade de delegados que nunca estudaram ou cursaram apenas o primeiro grau. No que toca à identidade religiosa, o catolicismo mantevese como a mais mencionada entre os delegados, apresentando um leve crescimento entre 2001 e 2007. Esse dado não surpreende, pois, como foi apontado em outros trabalhos (MENEGUELLO, 1989; KECK, 1991; RODRIGUES, 1997), a ala progressista da Igreja Católica esteve muito presente nos anos de formação do partido e foi um dos elementos de construção da própria identidade ideológica do PT. É interessante notar, porém, que houve uma redução entre aqueles que não possuem religião e um crescimento dos que se afirmam evangélicos, que passaram de $2 \%$, em 1997, para 8,4\%, dez anos depois. Já os dados com relação à renda individual dos delegados precisam ser analisados com cuidado. À primeira vista, parece haver uma redução nos rendimentos, pois a porcentagem de delegados que ganham mais de 10 salários mínimos passou de 60\%, em 1999, para 34,6\%, em 2007. No entanto, como argumentamos em outro trabalho, esta redução pode ser

\footnotetext{
7 O Estatuto do PT estabelece, no seu Art. 22, inciso V, que 30\% dos integrantes da direção partidária devem ser mulheres (PT, 2001a, p. 32).

${ }^{8}$ Como forma de comparação, é interessante destacar que Méndez Lago e Santamaría, ao realizarem um survey semelhante com os delegados do PSOE, em 1999, encontraram resultados parecidos: predomínio de homens entre as lideranças (cerca de 75\%) e dificuldade de renovação de quadros (2001). Scarrow e Gezgor, ao analisarem dados relativos a filiados em 12 países europeus, também apontam para um processo de envelhecimento nos quadros partidários e para a manutenção da predominância de homens (2010).
} 
explicada, em grande medida, pelo aumento real do salário mínimo no período estudado (MENEGUELLO e AMARAL, 2008, p. 13) ${ }^{9}$.

Tabela 6

Perfil do delegado petista (\%)

\begin{tabular}{|c|c|c|c|c|c|}
\hline & $\begin{array}{l}1997 \\
11^{\circ} \mathrm{EN}\end{array}$ & $\begin{array}{l}1999 \\
2^{\circ} \mathrm{CN}\end{array}$ & $\begin{array}{l}2001 \\
12^{\circ} \mathrm{EN} \\
\end{array}$ & $\begin{array}{l}2006 \\
13^{\circ} \mathrm{EN}\end{array}$ & $\begin{array}{l}2007 \\
3^{\circ} \mathrm{CN}\end{array}$ \\
\hline \multicolumn{6}{|l|}{ Condição de trabalho ${ }^{10}$} \\
\hline Funcionários públicos & 33 & 49 & 44,3 & 54,3 & - \\
\hline Assalariados & 32 & 23 & 20,2 & 12,5 & - \\
\hline Profissionais liberais & 9 & 6 & 7,7 & 6,9 & - \\
\hline Autônomos & 3 & 2 & 5,3 & 9,0 & - \\
\hline $\mathbf{N}$ & & & & (289) & \\
\hline \multicolumn{6}{|l|}{ Escolaridade $^{11}$} \\
\hline Nuca estudou & - & - & - & 0,1 & 0,1 \\
\hline $1^{\circ} \mathrm{grau}$ & 5 & 5 & 3,7 & 2,2 & 4,9 \\
\hline $2^{\circ}$ grau & 21 & 22 & 13,0 & 16,0 & 19,0 \\
\hline Superior & 62 & 57 & 64,7 & 68,1 & 65,7 \\
\hline Mestrado/Doutorado & 11 & 14 & 18,3 & 12,6 & 9,8 \\
\hline Sem resposta & 1 & 1 & 0,2 & 1 & 0,5 \\
\hline \multicolumn{6}{|l|}{ Renda individual } \\
\hline Até 2 sm & 6 & 6 & 4,6 & 6,0 & 7,5 \\
\hline De 2 a 5 sm & 14 & 9 & 11,8 & 19,1 & 25,5 \\
\hline De 5 a $10 \mathrm{sm}$ & 19 & 22 & 23,2 & 33,0 & 31,6 \\
\hline De 10 a $20 \mathrm{sm}$ & 27 & 34 & 34,3 & 26,4 & 24,3 \\
\hline Mais de $20 \mathrm{sm}$ & 28 & 26 & 23,7 & 13,4 & 10,3 \\
\hline Sem resposta & 6 & 3 & 2,3 & 2,1 & 0,8 \\
\hline
\end{tabular}

\footnotetext{
${ }^{9}$ Singer sugere que o aumento no número de delegados de menor renda pode ser explicado pelo realinhamento na base de apoio do partido, com a maior penetração da agremiação entre segmentos de baixa renda e escolaridade (2010, p. 100). Embora não discordemos da hipótese de que a base de filiados ao PT possa estar em transformação, não concordamos com a argumentação do autor com relação aos dados obtidos com as lideranças petistas, pois o nível de escolaridade entre os delegados permanece elevado e a porcentagem de novos membros (filiados desde 2001) é relativamente pequena (7,1\% em 2006 e 8,6\% em 2007) (DELEGADOS-PT/FPA, 2006; 2007) para explicar tal variação no nível de renda.

10 Os dados relativos a 2006 foram obtidos no survey realizado pelo autor. As categorias retratadas foram as mais citadas em 2006.

${ }^{11}$ Os dados relativos à escolaridade referem-se aos delegados que chegaram ao menos a frequentar cada categoria.
} 
OPINIÃO PÚBLICA, Campinas, vol. 17, no 1, Junho, 2011 , p.01-44

\begin{tabular}{|l|l|l|l|l|l|}
\hline Idade & & & & & \\
Até 25 anos & 5 & 5 & 3,5 & 4,3 & 1,7 \\
De 26 a 30 anos & 13 & 9 & 8,6 & 6,9 & 6,3 \\
De 31 a 40 anos & 46 & 41 & 40,4 & 29,5 & 27,1 \\
41 anos ou mais & 32 & 38 & 45,9 & 59,0 & 64,8 \\
Sem resposta & 4 & 6 & 1,6 & 0,2 & 0,1 \\
\hline Sexo & & & & & \\
Homens & 80 & 77 & 71,7 & 75,6 & 80 \\
Mulheres & 20 & 23 & 28,3 & 24,4 & 20 \\
\hline Religião & & & & & \\
Católica & 57 & 59 & 58,7 & 62,7 & 66,5 \\
Espírita & 5 & 3 & 2,1 & 6,1 & 5,2 \\
Umbanda & 1 & - & 0,5 & 2,8 & 1,5 \\
Evangélica & 2 & 2 & 1,4 & 9,7 & 8,4 \\
Não tem & 30 & 31 & 33,4 & 24,5 & 22,2 \\
Outras & 4 & 3 & 3,9 & 6,3 & 5,2 \\
Sem resposta & 1 & 2 & 0,7 & 0,2 & 0,3 \\
\hline $\mathbf{N}$ & $\mathbf{( 1 8 7 )}$ & $\mathbf{( 5 4 4 )}$ & $\mathbf{( 4 3 1 )}$ & $\mathbf{( 8 6 4 )}$ & $\mathbf{( 7 7 5 )}$ \\
\hline
\end{tabular}

Fontes: NOP da FPA e pesquisa realizada pelo autor no $13^{\circ} \mathrm{EN}$ do PT.

As mudanças mais significativas no perfil social da liderança petista estão ligadas às suas condições de trabalho. Como mostrou Rodrigues, o PT poderia ser classificado, em meados dos anos 1990, como um partido de classe média, com o predomínio de assalariados com alto nível de escolaridade, em especial funcionários públicos e líderes sindicais (1997, p. 306). Como acabamos de mostrar, boa parte desse perfil se manteve nos últimos 13 anos. No entanto, a predominância de funcionários públicos entre as lideranças aumentou significativamente entre 1997 e 2006. No 13 EN, 54,3\% dos delegados afirmaram ser funcionários públicos. Nove anos antes, a porcentagem era de $33 \%$. Nesse mesmo período, a parcela de assalariados caiu de $32 \%$ para $12,5 \%$. São dois os fatores que contribuíram para esse crescimento dos funcionários públicos entre a liderança petista. O primeiro - e mais importante - está ligado à proximidade dos sindicatos de setores do serviço público ao partido, especialmente a partir dos anos 1990. De acordo com Samuels, a reestruturação produtiva provocada pelo avanço de políticas pró-mercado fez com que grupos de base tradicionais do PT e da Central Única dos Trabalhadores (CUT), como trabalhadores da indústria e bancários, perdessem força política e cedessem espaço a outros segmentos organizados, como os trabalhadores do serviço público, resultando em uma

\footnotetext{
12 Para 2001, 2006 e 2007, resposta múltipla.
} 
importante alteração na base de apoio do partido (2004, p. 1006-1007). O segundo é consequência da maior inserção institucional do PT. Mostra a Tabela 7, a partir de 1997 houve uma ampliação na porcentagem de delegados que ocupavam cargos de confiança no Executivo e no Legislativo, o que provavelmente contribuiu para a elevação na proporção de funcionários públicos entre a liderança petista no período analisado. Como não dispomos de dados a respeito das ocupações daqueles que afirmaram ser funcionários públicos em 1997, 1999 e 2001, é impossível saber quantos deles ocupavam cargos de confiança no Executivo ou no Legislativo, o que impossibilita uma medida precisa de seu impacto sobre o perfil sócio-ocupacional dos delegados. Em que pesem os problemas metodológicos, a ampliação do espaço ocupado pelos funcionários públicos no partido a partir dos anos 1990 confirma a tendência verificada por Rodrigues (1997), Samuels (2004), Meneguello e Amaral (2008) e D'Araujo (2009).

Os dados relativos à profissionalização na política também indicam importantes alterações no perfil da liderança petista no período analisado ${ }^{13}$. A história que os números contam é a da inversão, durante a década de 1990, na proporção entre os profissionalizados nas esferas estatais e fora dela. Como podemos observar na Tabela 7, em 1990,35,5\% dos delegados exerciam atividade política remunerada fora do Estado, enquanto 22,1\% ocupavam cargos eletivos ou postos de confiança no Executivo e no Legislativo. Onze anos depois, a tendência se alterou substantivamente $-16,5 \%$ eram profissionais da política fora da esfera estatal, enquanto $53,1 \%$ ocupavam cargos eletivos ou comissionados. Como aponta a literatura, essa inversão foi resultado da maior inserção institucional do PT no período, com o crescimento no número de parlamentares e mandatários no Executivo em todos os níveis (SINGER, 2001; MENEGUELLO e AMARAL, 2008; RIBEIRO, 2008). É interessante notar que, embora predominantes entre os profissionalizados, o número de ocupantes de cargos eletivos e de confiança caiu entre 2001 e 2007, atingindo 34,4\%. Alguns fatores parecem ter contribuído de forma combinada para essa queda: o primeiro é o expressivo aumento no número de delegados que passaram a comparecer aos Encontros (538 em 2001; $1.053 \mathrm{em}$ 2006; e 927 em 2007), o que ampliou a possibilidade de incorporação das lideranças aos processos deliberativos do partido. O segundo é a substantiva redução na porcentagem de delegados profissionalizados na esfera estatal no estado de São Paulo, que caiu de $69,1 \%$ para $33,1 \%$ no período. Como São Paulo é a UF que mais envia delegados aos Encontros Nacionais, alterações no perfil da delegação paulista refletem significativamente nos dados nacionais. É provável que o final da prefeitura de Marta Suplicy na capital paulista, em 2004, tenha contribuído para essa redução. O terceiro fator, levantado por Ribeiro, é o

13 Classificamos como "profissionais da política" os delegados que são remunerados para exercer atividade política. 
OPINIÃO PÚBLICA, Campinas, vol. 17, no 1, Junho, 2011 , p.01-44

deslocamento de milhares de quadros petistas para Brasília com a vitória de Lula em 2002. Esse deslocamento pode ter afastado um número significativo de lideranças intermediárias de suas atividades partidárias locais, impactando nas delegações enviadas aos Encontros (2008, p. 154). Para que um quadro mais claro a respeito dessa diminuição apareça, será necessário analisar os dados das futuras pesquisas com os delegados petistas.

Tabela 7

Tipo de profissionalização política entre os delegados (\%)

\begin{tabular}{|c|c|c|c|c|c|c|c|}
\hline & $\begin{array}{l}1990 \\
7^{\circ} \mathrm{EN}\end{array}$ & $\begin{array}{l}1991 \\
1^{\circ} \mathrm{CN}\end{array}$ & $\begin{array}{l}1997 \\
11^{\circ} \mathrm{EN}\end{array}$ & $\begin{array}{l}1999 \\
2^{\circ} \mathrm{CN}\end{array}$ & $\begin{array}{c}2001 \\
12^{\circ} \mathrm{EN}\end{array}$ & $\begin{array}{c}2006 \\
13^{\circ} \\
\text { EN }\end{array}$ & $\begin{array}{c}2007 \\
3^{\circ} \\
\mathrm{CN}\end{array}$ \\
\hline Não é profissionalizado & 40,8 & 40,2 & 31,0 & 34,0 & 25,5 & 51,7 & 59,1 \\
\hline $\begin{array}{l}\text { Cargo eletivo no } \\
\text { Executivo/Legislativo }\end{array}$ & 10,9 & 11,5 & 19,0 & 18,0 & 23,9 & 14,8 & 15,9 \\
\hline $\begin{array}{l}\text { Cargo de confiança no } \\
\text { Executivo/Legislativo }\end{array}$ & 11,2 & 17,0 & 21,0 & 24,0 & 29,2 & 24,5 & 18,5 \\
\hline $\begin{array}{l}\text { Profissionalizado pelo PT } \\
\text { (dirigente ou assessor) }\end{array}$ & 7,2 & 8,6 & 7,0 & 6,0 & 9,7 & 4,7 & 3,4 \\
\hline $\begin{array}{l}\text { Militante profissionalizado } \\
\text { pela tendência }\end{array}$ & $\cdot$ & & 2 & 2,0 & 2,1 & 0,3 & 0,4 \\
\hline $\begin{array}{l}\text { Profissionalizado por } \\
\text { movimento social }\end{array}$ & 28,3 & 17,5 & 9,0 & 6,0 & 2,1 & 2,7 & 0,9 \\
\hline Outras atividades & - & 1,6 & \multirow{2}{*}{11,0} & \multirow{2}{*}{9,0} & 2,6 & 0,5 & 1,8 \\
\hline Sem resposta & 1,6 & 3,6 & & & 4,9 & 0,7 & 0,1 \\
\hline $\mathbf{N}$ & (289) & (671) & (187) & (544) & (431) & (864) & (775) \\
\hline
\end{tabular}

Fontes: Novaes (1993, p. 228), Ribeiro (2008, p. 152) e NOP da FPA.

A recente redução na porcentagem de delegados profissionalizados na esfera estatal não invalida, porém, a constatação de que as lideranças, especialmente aquelas que exercem atividade política remunerada, aproximaram-se do Estado a partir da década de 1990. Essa constatação encontra paralelos na literatura sobre os partidos social-democratas europeus (POGUNTKE, 1994; SHARE, 1999; MÉNDEZ LAGO e SANTAMARÍA, 2001). Share observa que, em 1988, $70 \%$ dos delegados presentes ao Congresso do PSOE, que governava a Espanha havia seis anos, ocupavam cargos eletivos ou postos administrativos (1999, p. 98). Méndez Lago e Santamaría encontraram a mesma porcentagem entre os delegados que compareceram ao 34 Congresso da agremiação, em 1997 (2001, p. 60). Katz e Mair, em uma perspectiva teórica mais ampla, usam dados como esses para 
justificar a ascendência da face pública do partido e a emergência do modelo de partido cartel (2002).

Com relação ao caso petista, Ribeiro foi o primeiro a defender, de maneira estruturada e coerente, que o PT se aproximou do Estado e se afastou dos atores da sociedade civil. Um ponto importante da sua argumentação reside na avaliação de que o partido se distanciou dos movimentos e das organizações sociais conforme se aproximou do Estado, e um dos indicadores que usa deriva dos dados obtidos com os delegados presentes aos Encontros Nacionais do partido (2008, p. 164-166). Não concordamos com essa avaliação e mostramos, deste ponto em diante, que o PT continua permeável à participação de atores da sociedade civil organizada ${ }^{14}$.

Começamos por demonstrar que não há uma associação inversa significativa entre a profissionalização em cargos públicos e a participação em movimentos ou organizações sociais, como afirma Ribeiro (2008, p. 165). Demonstramos isso ao testar o grau de associação entre a porcentagem de delegados que ocupavam cargos eletivos e de confiança, por UF, e a de delegados que participavam de movimentos ou organizações sociais em 2001, 2006 e 2007 (Tabela 8). Conforme mostram os testes, não é possível afirmar que os estados em que há uma maior porcentagem de delegados ocupando postos eletivos ou comissionados são aqueles em que há baixos níveis de participação em movimentos ou organizações sociais. Dessa forma, também não é possível supor que as lideranças deixem de participar de movimentos ou organizações sociais ao se profissionalizarem na esfera estatal.

\section{Tabela 8}

Correlação entre a porcentagem de delegados profissionalizados em esferas estatais e a de delegados que participam de movimentos ou organizações sociais, por UF ( $r$ de Spearman)

\begin{tabular}{|c|c|c|c|}
\hline & Participação & & \\
\hline \multirow[t]{2}{*}{ Profissionalização } & $2001\left(12^{\circ} \mathrm{EN}\right)$ & $2006\left(13^{\circ} \mathrm{EN}\right)$ & $2007\left(3^{\circ} \mathrm{CN}\right)$ \\
\hline &,- 167 &,- 214 & -,010 \\
\hline
\end{tabular}

Fonte: NOP da FPA. Nenhuma das correlações mostrou-se significativa $(p<0,1)$.

$N=26$ para 2001 e 2006 (o estado de Roraima foi excluído por não haver dados sobre seus delegados); $\mathrm{N}=27$ para 2007.

\footnotetext{
14 Não é nosso objetivo fazer uma discussão sobre a natureza dos movimentos e das organizações sociais próximos ao PT, mas mostrar o grau de vinculação do partido a atores da sociedade civil organizada de uma forma ampla.
} 
OPINIÃO PÚBLICA, Campinas, vol. 17, no 1, Junho, 2011 , p.01-44

Nosso argumento é o de que, no lugar de haver um deslocamento entre a liderança dos movimentos e das organizações sociais para o Estado, o que acontece é uma dupla atividade. Ou seja, os delegados permanecem com seus vínculos junto aos movimentos e organizações sociais ao mesmo tempo em que desempenham atividades em posições eletivas ou cargos de confiança. A Tabela 9 mostra que, entre 2001 e 2007, o nível de participação em movimentos ou organizações sociais entre os delegados profissionalizados junto ao Estado manteve-se em torno de $65 \%$, uma porcentagem bastante significativa apesar de levemente mais baixa do que o nível de participação entre as lideranças como um todo. Embora não seja possível realizar comparações com o período anterior a 2001, esses dados mostram que o PT, apesar de todas as transformações pelas quais passou a partir da segunda metade da década de 1990, ainda serve como importante conexão entre o Estado e os movimentos e organizações sociais. Voltaremos a esse tema nas Considerações finais.

Tabela 9

Participação dos delegados que ocupam cargos de confiança ou eletivos em movimentos ou organizações sociais (\%)

\begin{tabular}{|l|l|l|l|}
\hline & $\mathbf{2 0 0 1}$ & $\mathbf{2 0 0 6}$ & $\mathbf{2 0 0 7}$ \\
& $\mathbf{1 2}^{\circ} \mathbf{E N}$ & $\mathbf{1 3}^{\circ} \mathbf{~ E N}$ & $\mathbf{3}^{\circ} \mathbf{~ C N}$ \\
\hline Delegados & 69,6 & 71,9 & 70,9 \\
$\mathbf{N}$ & $(431)$ & $(864)$ & $(385)$ \\
\hline Ocupantes de cargos de confiança ou eletivos & 65,1 & 66,2 & 65,4 \\
$\mathbf{N}$ & $(229)$ & $(340)$ & $(127)$ \\
\hline
\end{tabular}

Fonte: NOP da FPA.

Os dados referentes à participação dos delegados em movimentos e organizações sociais exigiram uma readequação na classificação para as respostas dadas pelas lideranças petistas nos Encontros de 2006 e 2007. Excluímos os delegados que, indagados se participavam de algum movimento ou organização social, responderam positivamente e mencionando instituições ligadas ao próprio PT, como o Setorial de Mulheres, ou ligadas ao Estado, como os conselhos municipais ou a Funai. Após essa exclusão, prosseguimos com a reclassificação de acordo com as categorias utilizadas nas pesquisas realizadas em 1997 e 2001. Além da reclassificação, outro alerta de natureza metodológica precisa ser feito. 0 elevado número de respostas encontradas na categoria "Outros" deve-se à alteração na metodologia das pesquisas. O autopreenchimento de questionários em 1997 e 2001 limitava as respostas possíveis, o que provavelmente redundou em uma tentativa do próprio pesquisado em se enquadrar em uma das categorias 
disponíveis. Em 2006 e 2007, as pesquisas foram feitas por meio de entrevistas, o que permitiu aos delegados mencionar diretamente a organização ou o movimento dos quais faziam parte.

Durante todo o período analisado há um forte vínculo das lideranças com os movimentos e as organizações sociais (Tabela 10). Entre 1997 e 2007, cerca de $70 \%$ dos delegados afirmaram fazer parte de algum tipo de movimento ou organização social. Muitos dos delegados faziam parte de mais de um movimento e eram tanto dirigentes quanto militantes de base. Se por um lado é possível notar uma tendência de redução na porcentagem daqueles que não ocupavam postos de direção nos movimentos e nas organizações, sugerindo uma crescente dificuldade do partido em incorporar quadros de base dos movimentos sociais ao grupo dos delegados, por outro, a manutenção de um alto número de dirigentes aponta que o partido é capaz de atrair lideranças dos movimentos e organizações, indicando a preservação de laços fortes entre a agremiação e a sociedade civil organizada. Com relação à natureza dos movimentos e organizações, é possível observar que os grupos de origem do partido, como sindicalistas e membros de organizações religiosas, continuam sendo os mais representativos. Em 2006, quando a amostra foi maior, 47 sindicatos e 11 pastorais da Igreja Católica foram mencionados pelos delegados. A exceção nesse caso fica por conta dos movimentos populares urbanos. No entanto, é preciso relativizar essa queda, pois a categoria "Outros" conta com associações de bairro e moradores - organizações sociais que provavelmente entraram na categoria "Movimentos Populares Urbanos" em 1997 e 2001.0 envelhecimento dos delegados provocou um impacto na representação dos estudantes e jovens. Entre 2001 e 2007, a porcentagem de delegados associados aos movimentos estudantis e de juventude passou de $8,5 \%$ para $2,3 \%$. 
OPINIÃO PÚBLICA, Campinas, vol. 17, no 1, Junho, 2011 , p.01-44

Tabela 10

Participação dos delegados em movimentos ou organizações sociais (\%)

\begin{tabular}{|l|l|l|l|l|}
\hline & $\mathbf{1 9 9 7}\left(\mathbf{1 1}^{\mathbf{0}} \mathbf{E N}\right)$ & $\mathbf{2 0 0 1}\left(\mathbf{1 2}^{\mathbf{0}} \mathbf{E N}\right)$ & $\mathbf{2 0 0 6}\left(\mathbf{1 3}^{\circ} \mathbf{~ E N}\right)$ & $\left.\mathbf{2 0 0 7} \mathbf{( 3}^{\circ} \mathbf{~ C N}\right)$ \\
\hline Participam & 70 & 69,6 & 71,9 & 70,9 \\
\hline Direção & - & 69,4 & 73,8 & 69,6 \\
\hline Mil. de base & - & 86,0 & 70,7 & 62,3 \\
\hline \% do total dos delegados & 31 & 28,6 & 30,7 & 24,4 \\
\hline Sindical & 23 & 17,4 & 11,0 & 6,2 \\
\hline Pop. Urbano & 3 & 3,5 & 1,7 & 2,6 \\
\hline MST & 9 & 11,1 & 6,7 & 6,0 \\
\hline Mulheres & 4 & 5,1 & 3,2 & 3,6 \\
\hline Racismo/Negro & 7 & 8,5 & 5,2 & 2,3 \\
\hline Estudantil/Juv. & 7 & 8,6 & 3,2 & 3,4 \\
\hline Ecol./Ambiental & 6 & 1,1 & 0,3 &. \\
\hline Gays/Lésbicas & 2 & 7,4 & 8,6 & 7,5 \\
\hline Orgs. Religiosas & 9 & 10,9 & 3,7 & 4,7 \\
\hline ONGs & 9 & 6,2 & 30,0 & 33,8 \\
\hline Outros & 10 & $\mathbf{( 4 3 1 )}$ & $\mathbf{( 8 6 4 )}$ & $\mathbf{( 3 8 5 )}$ \\
\hline N & $\mathbf{( 1 8 7 )}$ & &
\end{tabular}

Fonte: NOP da FPA.

Um dado complementar ao nível de participação dos delegados em movimentos ou organizações sociais é o que nos permite identificar se a liderança petista possuía algum vínculo com atores da sociedade civil quando entrou para a agremiação. Esse dado torna possível descobrir os padrões de recrutamento dos delegados e as portas de entrada para o partido. Infelizmente, a FPA não aplicou essa pergunta nas pesquisas anteriores a 2007, impossibilitando comparações diacrônicas. Como mostramos na Tabela 11, 82,9\% dos delegados estavam ligados a algum movimento ou organização quando entraram no partido. Os dados desagregados por período de filiação não mostram grande variação, e mesmo as lideranças com menos tempo de PT entraram no partido possuindo vínculos com atores da sociedade civil organizada (Tabela 12).

Ao observarmos as origens das lideranças junto aos movimentos e às organizações sociais, é possível identificar que três categorias se destacam: "Movimento Sindical", "Organizações Religiosas" e "Movimento Estudantil e de Jovens". Ou seja, foi a partir desses movimentos que mais de $70 \%$ dos delegados entraram no PT. No entanto, há sinais de mudança nos padrões de recrutamento quando observamos os dados desagregados por período de filiação. Entre os que 
entraram no período 1980-1982 e participavam de movimentos ou organizações sociais, $47,1 \%$ estavam vinculados a sindicatos. Essa porcentagem foi declinando até atingir, entre os que ingressaram a partir de 2001, 20,7\%. Tendências semelhantes aconteceram com os que entraram no partido possuindo ligação com o movimento estudantil e com organizações religiosas. Paralelamente, a porcentagem de delegados com vinculação a "Outros" movimentos e organizações sociais no momento de filiação cresceu de 17,5\%, dos que ingressaram entre 1995 e 2000, para $51,7 \%$, entre os membros a partir de 2001 . Esse é um dado importante que pode significar o início da erosão da predominância dos atores tradicionais da sociedade civil organizada, especialmente sindicatos, entre a liderança petista. Se a tendência se confirmar, não é difícil imaginar que o partido sofrerá mudanças tanto no perfil das suas lideranças intermediárias quanto na sua cúpula, resultando, muito provavelmente, também em alterações programáticas. No entanto, com os dados de que dispomos no momento, não é possível prever qualquer cenário de forma segura.

Tabela 11

Participação dos delegados em movimentos ou organizações sociais no momento de entrada no PT (\%)

\begin{tabular}{|l|l|}
\hline & $\mathbf{2 0 0 7}\left(\mathbf{3}^{\mathbf{0}} \mathbf{C N}\right)$ \\
\hline Participantes & 82,9 \\
\hline Direção & 72,1 \\
\hline Mil. de base & 52,0 \\
\hline \% do total dos delegados \\
\hline Sindical & 29,9 \\
\hline Pop. Urbano & 8,1 \\
\hline MST & 2,9 \\
\hline Mulheres & 2,1 \\
\hline Racismo/Negro & 1,3 \\
\hline Estudantil/Juv. & 21,8 \\
\hline Ecol./Ambiental & 1,0 \\
\hline Gays/Lésbicas & - \\
\hline Orgs. Religiosas & 21,6 \\
\hline ONGs & 0,8 \\
\hline Outros & 19,0 \\
\hline N & $(385)$ \\
\hline
\end{tabular}

Fonte: NOP da FPA. 
OPINIÃO PÚBLICA, Campinas, vol. 17, no 1, Junho, 2011 , p.01-44

Tabela 12

Participação dos delegados em movimentos ou organizações sociais no momento de entrada no PT (\%) X Período de filiação

\begin{tabular}{|l|l|}
\hline \multicolumn{2}{|l|}{2007 (3 $\mathbf{~ C N )}$} \\
\hline Filiação & Participava (\%) \\
\hline $1980-1982$ & 81,4 \\
\hline $1983 \cdot 1989$ & 84,3 \\
\hline $1990 \cdot 1994$ & 87,0 \\
\hline $1995 \cdot 2000$ & 80,3 \\
\hline $2001 \cdot 2007$ & 82,9 \\
\hline $\mathbf{N}$ & $\mathbf{( 3 8 0 )}$ \\
\hline
\end{tabular}

Fonte: NOP da FPA.

O perfil analisado da liderança petista a partir da segunda metade da década de 1990 mostra que os padrões de alteração identificados por Rodrigues (1997) e Novaes (1993) se confirmaram e o PT é hoje comandado por dirigentes de classe média, com alto nível de escolaridade e com grande presença de setores do funcionalismo público. Além disso, a maior presença institucional do partido exerceu influência sobre o perfil das lideranças ao alterar a proporção de delegados que são remunerados em esferas estatais para exercer atividades políticas. Nesse ponto, concordamos com a avaliação de Ribeiro (2008) de que o PT que chega ao final do governo Lula está muito mais próximo do Estado do que aquele que perdeu as eleições presidenciais de 1989. No entanto, não concordamos com a hipótese de que o partido se afastou significativamente dos movimentos e das organizações sociais em consequência dessa maior proximidade. A análise dos dados obtidos junto aos delegados petistas, demonstra que o partido continua bastante permeável à participação de atores da sociedade civil organizada e suas lideranças realizam atividades políticas tanto nas instituições estatais quanto junto aos movimentos e organizações sociais.

\section{Considerações finais}

Nos últimos anos, muitos trabalhos se preocuparam em analisar as transformações do PT a partir de meados da década de 1990 e a atuação do partido durante o governo Lula (AMARAL, 2003; SAMUELS, 2004; 2008b; FLYNN, 2005; PALERMO, 2005; HUNTER, 2007; 2008a; 2008b; 2010). O material para análise era realmente imenso: transformações ideológicas, alianças eleitorais e políticas com partidos de direita, dificuldades na formação do governo e escândalos de corrupção. As conclusões de todos eles giraram em torno da aproximação do PT 
aos outros partidos do país na busca por maior competitividade eleitoral, ou como resultado das pressões exercidas pela natureza do sistema político brasileiro e pelas reformas pró-mercado dos anos 1990. Hunter, inclusive, chegou a afirmar que o partido havia passado por um processo de "normalização" (2007; 2010), revertendo a clássica visão de que o PT era "diferente" que marcou as primeiras análises sobre a agremiação (MENEGUELLO, 1989; KECK, 1991). Apesar de fornecerem ferramentas analíticas valiosas para a compreensão da história recente do partido, esses trabalhos pouco se debruçaram sobre as transformações na base de filiados do PT e na avaliação de sua conexão com os atores da sociedade civil organizada e deixaram escapar importante dimensão na análise dos partidos políticos: sua organização interna. Neste artigo buscamos preencher essa lacuna e nos juntamos, nesta empreitada, aos trabalhos de Roma (2006) e Ribeiro (2008), embora com algumas conclusões distintas.

Na primeira parte do artigo demonstramos que o PT obteve sucesso, a partir de 2003, em ampliar significativamente a sua base de filiados. Essa ampliação esteve diretamente ligada a questões de organização interna do partido, como a construção de uma máquina partidária mais eficiente, o esforço de nacionalização da estrutura petista e a redução nas barreiras de inclusão e nos custos de participação do filiado na vida da agremiação. As transformações do partido nesse sentido não ocorreram sem tensões ou resistências internas e foram marcadas pela preservação de algumas características institucionais importantes, como a manutenção de mecanismos deliberativos participativos e a ausência de práticas clientelistas em larga escala.

Ainda com relação à redução das barreiras de inclusão, encontramos duas novidades ainda não exploradas em profundidade pela literatura. A primeira delas é uma consequência indireta das transformações ideológicas e programáticas do partido. Mais próximo do centro do espectro político, o PT conquistou uma série de novos apoiadores (SAMUELS, 2008a), ampliando o número de potenciais filiados. 0 sucesso das campanhas de filiação em 2003 e 2006 parece ter se beneficiado desse maior "território de caça" aberto pela moderação ideológica. A segunda diz respeito à maior facilidade em captar membros, entre 2006 e 2008, nos locais em que o presidente Lula obteve votações mais expressivas. Embora a partir de uma perspectiva diferente, essa evidência insere-se no debate sobre as transformações na base de apoio do presidente Lula nas eleições de 2006 e suas consequências políticas (HUNTER e POWER, 2007; ZUCCO, 2008; SOARES e TERRON, 2008; 2010; LÍCIO, RENNÓ e CASTRO, 2009; SINGER, 2009; RENNÓ e CABELLO, 2010). No lugar de nos concentrarmos nos determinantes da mudança na base de apoio, sugerimos que a alta popularidade do presidente Lula e de seu governo em algumas regiões do país tenha sido aproveitada como recurso político e organizativo pelo PT. Nesse sentido, seguimos as indicações de Meneguello, que apontou a existência de 
uma forte associação entre o presidente da República e o PT, mesmo após os esforços de Lula em se distanciar da agremiação com a eclosão do "escândalo do mensalão" em 2005 (2007, p. 12). Sendo assim, é possível levantarmos a hipótese de que o fenômeno do "Lulismo" tenha também uma dimensão partidária. Os trabalhos de Singer (2010) e Samuels e Zucco (2010) demonstram que o apoio partidário de massa ao PT sofreu importantes alterações na última década, com o perfil do petista aproximando-se ao do eleitorado brasileiro. É possível imaginarmos que algo semelhante tenha ocorrido com a base de filiados ao partido. Dessa forma, o "Lulismo" teria deixado o conjunto de membros do PT com uma feição um pouco mais próxima à da sociedade brasileira.

A análise do perfil dos delegados demonstram que o caminho trilhado pelo partido nos anos 1980, com a adesão de segmentos da classe média urbana à proposta de construção de um partido amplo de esquerda (RODRIGUES, 1997), se confirmou nos últimos anos. O PT que chega ao final do governo Lula é comandado, na sua maioria, por lideranças do sexo masculino, católicas, com mais de 40 anos, que frequentaram algum curso superior e estão ligadas ao serviço público. Dada a estabilidade nos dados, especialmente entre 2001 e 2007, acreditamos que esse perfil deva se manter por algum tempo.

Já com relação ao binômio Estado/Sociedade, demonstramos que, como aponta Novaes (1993) e como argumenta Ribeiro (2008), o PT se aproximou das esferas estatais nos anos 1990, em grande medida como resultado da maior inserção na política institucional a partir daquela década. No entanto, essa aproximação não significou uma redução substantiva na permeabilidade do partido a atores da sociedade civil organizada. Como mostram os dados obtidos junto à liderança petista, os movimentos e as organizações sociais continuam presentes, inclusive entre aqueles que ocupam cargos eletivos e de confiança e indicam que uma importante conexão entre o Estado e a sociedade civil organizada por meio do PT. Hochstetler defende que, durante o governo Lula, o PT perdeu o monopólio de representação na arena institucional das demandas dos atores da sociedade civil organizada devido à continuidade da política econômica implantada na administração anterior e à decepção no desenvolvimento de mecanismos participativos sólidos no âmbito federal (2008). A nossa análise indica que o argumento da autora se confirma apenas em parte, especialmente quando observamos que atores tradicionais da sociedade civil organizada, como os sindicatos, vêm perdendo espaço entre as lideranças partidárias - o que pode redundar em transformações na agremiação. No entanto, o quadro mais amplo aponta para o fato de que o PT ainda conta, em suas fileiras, com um grande número de militantes e, principalmente, dirigentes de movimentos e organizações sociais e que esses números não declinaram entre 1997 e 2007, sugerindo que os próprios atores da sociedade civil organizada ainda enxergam o partido como um 
representante institucional aberto às suas demandas e capaz de compartilhar propostas políticas.

Se não é mais possível falar em "monopólio" de representação, ainda podemos falar em um substantivo grau de interface. Como explicação para a manutenção dessa interface podemos apontar dois elementos: a construção de uma história conjunta marcada pela experiência da redemocratização e pela emergência da "esquerda social" (GARCIA, 1994) nos anos 1980, responsável, em parte, pelo próprio perfil programático e organizacional do partido. Essa história resultou na aquisição por parte da agremiação de uma posição privilegiada de articulação e representação de amplos setores de esquerda junto ao sistema partidário brasileiro a partir da eleição presidencial de 1989, na qual o partido se afirmou claramente como a principal força política progressista (MENEGUELLO e AMARAL, 2008, p. 6); e a ausência de alternativas institucionais - como outros partidos - com a mesma capilaridade, organização e influência política que o PT.

A discussão realizada neste artigo evidencia as dificuldades de interpretação do caso petista. Parece claro que, mesmo depois das transformações apontadas pela literatura, o PT conserva muitas das características que o apontaram como uma "novidade" na política brasileira. Se está mais próximo do modelo profissional-eleitoral, como defende Ribeiro (2008), ainda retém características que permitiriam enquadrá-lo como um "partido de massa", para usarmos apenas uma entre as inúmeras tipologias sobre partidos políticos existentes. Hunter, apesar de se concentrar na "normalização" do PT, observa que a adaptação do partido às restrições políticas e econômicas que emergiram no Brasil nos anos 1990 não foi completa, e que a agremiação manteve muitas das suas características organizativas $(2007 ; 2010)$. De um ponto de vista mais abrangente, esse foi o foco da nossa análise a respeito dos vínculos do partido com a sociedade a partir da segunda metade da década de 1990. Seguindo as pistas indicadas pelo institucionalismo histórico, mostramos que o PT retém muitas de suas características originárias, para usarmos uma terminologia cara aos estudiosos de partidos políticos (PANEBIANCO, 2005), e que suas transformações são graduais e moldadas pela origem e pela história da agremiação. Dessa forma, este artigo sugere, como implicação teórica mais ampla, que o estudo dos partidos deve sempre levar em consideração as práticas e regras construídas ao longo da vida das agremiações, fundamentais para o entendimento do contorno e do ritmo de seu desenvolvimento.

\section{Referências bibliográficas}

ALCÁNTARA SAEZ, M. e FREIDENBERG, F. Organización y funcionamiento interno de los partidos políticos en América Latina. In: ALCÁNTARA SAEZ, M. (Ed.). Partidos 
OPINIÃO PÚBLICA, Campinas, vol. 17, no 1, Junho, 2011, p.01-44

Políticos de América Latina. Centroamerica, México y República Dominicana. México D.F.: FCE, 2003.

ALMEIDA, J. Filiação sem política de organização. Boletim Nacional do PT, São Paulo, n64, 1992.

AMARAL, O. E. A estrela não é mais vermelha: as mudanças do programa petista nos anos 90. São Paulo: Garçoni, 2003.

. Adaptação e resistência: O PT no Governo Lula entre 2003 e 2008. Revista Brasileira de Ciência Política, Brasília, v. 4, p. 105-134, jul./dez. 2010.

BARTOLINI, S. The Membership of Mass Parties: the Social Democracy Experience 1889-1978. In: DAALDER, H. e MAIR, P. (Ed.). Western European Party Systems.

Continuity and Change. London: Sage, 1983.

BRAGA, M. S. S. Organizações partidárias e seleção de candidatos no estado de São Paulo. Opinião Pública, Campinas, v. 14, n. 2, p. 454-485, nov. 2008.

D'ARAUJO, M. C. A elite dirigente do governo Lula. Rio de Janeiro: CPDOC/FGV, 2009.

FLYNN, P. Brazil and Lula, 2005: crisis, corruption and change in political perspective. Third World Quarterly, London, v. 26, n. 8, p. 1221-1267, 2005.

FREIDENBERG, F. Mucho ruido y pocas nueces. Organizaciones partidistas y democracia interna en América Latina. Polis: Investigación y Análisis Sociopolítico y Psicosocial, Iztapalapa, v. 1, n. 1, p. 91-134, 2005.

FUNDAÇÃo PERSEU ABRAMO. Pesquisa - PT: Relatório Geral. São Paulo: FPA, 1997.

GARCIA, M. A. Esquerdas: rupturas e continuidades. In: DAGNINO, E. (Org.). Anos 90: política e sociedade no Brasil. São Paulo: Brasiliense, 1994.

GODINHO, T. Decidida campanha de filiação. Boletim Nacional do PT, São Paulo, n. 96, 1995.

HEIDAR, K. Party membership and participation. In: KATZ, R. e CROTTY, W. (Ed.). Handbook of Party Politics. London: Sage, 2006.

HOCHSTETLER, K. Organized Civil Society in Lula's Brazil. In: KINGSTONE, P. e POWER, T. (Ed.). Democratic Brazil Revisited. Pittsburgh: UPP, 2008.

HUNTER, W. The Normalization of an Anomaly: The Workers' Party in Brazil. World Politics, Princeton, n. 59, p. 440-475, 2007. 
. The Workers' Party: Still a Party of the Left? In: KINGSTONE, P. e POWER, T. (Ed.). Democratic Brazil Revisited. Pittsburgh: UPP, 2008a.

. The PT in Power: Shifting Policies and Patterns of Political Support. In: Latin America's Left Turn: Causes and Implications, Harvard University, p. 1-22, 2008b.

2010.

The Transformation of the Workers' Party in Brazil, 1989-2009. New York: CUP,

HUNTER, W. e POWER, T. Rewarding Lula: Executive Power, Social Policy, and the Brazilian Elections of 2006. Latin American Politics and Society, Miami, v. 49, n. 1, p. $1-30,2007$.

KATZ, R. e MAIR, P. The Ascendancy of the Party in Public Office: Party Organizational Change in Twentieth-Century Democracies. In: GUNTHER, R;

MONTERO, J. R. e LINZ, J. (Ed.). Political Parties: Old Concepts and New Challenges. Oxford: OUP, 2002.

HUNTER, W; et al. The Membership of Political Parties in European Democracies, 1960-1990. European Journal of Political Research, Amsterdam, n. 22, p. 329-345, 1992.

KECK, M. E. PT: a lógica da diferença; o Partido dos Trabalhadores na construção da democracia brasileira. São Paulo: Ática, 1991.

LAWSON, K. e MERKL, P. (Ed.). When Parties Fail: Emerging Alternative Organizations. Princeton: PUP, 1988.

LíCIO, E. C; RENNÓ, L. e CASTRO, H. C. O. Bolsa Família e Voto na Eleição Presidencial de 2006: em busca do elo perdido. Opinião Pública, Campinas, v. 15, n. 1 , p. 31-54, jun. 2009.

MÉNDEZ LAGO, M. La estrategia organizativa del Partido Socialista Obrero Español (1975-1996). Madrid: Siglo XXI, 2000.

MÉNDEZ LAGO, M.e SANTAMARÍA, J. La ley de disparidad ideológica curvilínea de los partidos políticos: el caso del PSOE. Revista Española de Ciencia Política, n. 4, p. 35-69, abr, 2001.

MENEGUELLO, R. PT: A formação de um partido, 1979-1982. São Paulo: Paz e Terra, 1989.

. Quem apoia o presidente? In: 2007 Congress of the Latin American Studies Association (Lasa), Montréal, p. 1-25, 2007. 
MENEGUELLO, R. e AMARAL, O. E. Ainda novidade: uma revisão das transformações do Partido dos Trabalhadores no Brasil. BSP Occasional Papers, Oxford, n. 2, p. 1-25, 2008.

NICOLAU, J. Partidos e Sistemas Partidários: 1985-2009. In: LESSA, R. (Org.). Horizontes das Ciências Sociais no Brasil: Ciência Política. São Paulo: ANPOCS, 2010.

NOVAES, C. A. M. PT: Dilemas da Burocratização. Novos Estudos Cebrap, São Paulo, n. 35, p. 217-237, mar. 1993.

PALERMO, V. Brasil. El gobierno de Lula y el PT. Nueva Sociedad, Buenos Aires, n. 192, p. 4-11, 2005.

PANEBIANCO, A. Modelos de partido: organização e poder nos partidos políticos. São Paulo: Martins Fontes, 2005.

PARTIDO DOS TRABALHADORES. Partido dos Trabalhadores: Resoluções de Encontros e Congressos (1979-1998). São Paulo: FPA, 1998.

- Resoluções do /l Congresso Nacional do Partido dos Trabalhadores. Belo Horizonte: PT, 1999. . Estatuto. São Paulo: FPA, 2001 a.

. Resoluções do $12^{\circ}$ Encontro Nacional do Partido dos Trabalhadores. São Paulo: PT/FPA, 2001 b.

POGUNTKE, T. Parties in a Legalistic Culture: The Case of Germany. In: KATZ, R. e MAIR, P. (Eds.). How Parties Organize: Change and Adaptation in Party Organizations in Western Democracies. London: Sage, 1994.

RENNÓ, L. e CABELLO, A. As bases do Lulismo: a volta do personalismo, realinhamento ideológico ou não alinhamento? Revista Brasileira de Ciências Sociais, São Paulo, v. 25, n. 74, p. 39-60, out. 2010.

RIBEIRO, P. Dos sindicatos ao governo: a organização nacional do PT de 1980 a 2005. São Carlos. 342 f. Tese (Doutorado em Ciência Política). Centro de Educação e Ciências Humanas da Universidade Federal de São Carlos, 2008.

RODRIGUES, L. M. PT: a New Actor in Brazilian Politics. In: DEVOTO, F. J. e DI TELLA, T. S. (Eds.). Political Culture, Social Movements and Democratic Transitions in South America in the 20 ${ }^{\text {th }}$ Century. Milan: Feltrinelli, 1997.

ROMA, C. Organizaciones de partido en Brasil: EI PT y el PSDB bajo perspectiva comparada. América Latina Hoy, Salamanca, n. 44, p. 153-184, 2006. 
SAMUELS, D. From Socialism to Social Democracy: Party Organization and the Transformation of the Workers' Party in Brazil. Comparative Political Studies, v. 37, n. 9, p. 999-1024, 2004.

A evolução do petismo (2002-2008). Opinião Pública, Campinas, v. 14, n. 2, p. 302-318, nov. 2008a.

. Brazilian Democracy under Lula and the PT. In: DOMINGUEZ, J. e SHIFTER, M. (Ed.). Constructing Democratic Governance in Latin America. Baltimore: Johns Hopkins University Press, 2008b.

e ZUCCO, C. The Roots of Petismo, 1989-2010. In: 2010 Meeting of the American Political Science Association (Apsa), Washington, 2010. p. 1-34.

SCARROW, S. E. The 'paradox of enrollment': Assessing the costs and benefits of party memberships. European Journal of Political Research, Amsterdam, n. 25, p. 41. 60, 1994.

e GEZGOR, B. Declining memberships, changing members? European political party members in a new era. Party Politics: OnlineFirst, London, 2010. p. 1 21.

SECRETARIA DE ORGANIZAÇÃO DO PT (SORG). Manual para a Campanha Nacional de Filiação. São Paulo: PT, 2003.

. Guia da Campanha de Filiação: Rio de Janeiro. São Paulo: PT, 2006.

SEYD, P. New Parties/New Politics?: A case study of the British Labour Party. Party Politics, London, v. 5, n. 3, p. 383-405, 1999.

. e WHITELEY, P. High-Intensity Participation: The Dynamics of Party Activism in Britain. Ann Harbor: UMP, 2002.

SHARE, D. From Policy-Seeking to Office-Seeking: The Metamorphosis of the Spanish Socialist Workers' Party. In: STROM, K. e MULLER, W. (Ed.). Policy, office or votes?: how political parties in Western Europe make hard decisions. Cambridge: CUP, 1999.

SINGER, A. O PT. São Paulo: Publifolha, 2001.

- Raízes sociais e ideológicas do Lulismo. Novos Estudos Cebrap, São Paulo, n. 85, p. 83-102, nov. 2009.

. A segunda alma do Partido dos Trabalhadores. Novos Estudos Cebrap, São

Paulo, n. 88, p. 89.111, nov. 2010. 
SOARES, G. e TERRON, S. Dois Lulas: a geografia eleitoral da reeleição (explorando conceitos, métodos e técnicas de análise geoespacial). Opinião Pública, Campinas, v. 14, n. 2, p. 269-301, nov. 2008.

As bases eleitorais de Lula e do PT: do distanciamento ao divórcio. Opinião Pública, Campinas, v. 16, n. 2, p. 310-337, nov. 2010.

VENTURI, G. PT 30 anos: crescimento e mudanças na preferência partidária. Perseu, São Paulo, n. 5, p. 197-214, 2010.

WARE, A. Political Parties and Party Systems. Oxford: OUP, 1996.

WAUTERS, B. Explaining Participation in Intra-party Elections: Evidence from Belgian Political Parties. Party Politics, London, v. 16, n. 2, p. 237-259, 2010.

ZUCCO, C. The President's 'New' Constituency: Lula and the Pragmatic Vote in Brazil's 2006 Presidential Elections. Journal of Latin American Studies, Cambridge, $n^{\circ}$ 40, p. 29.49, 2008.

\section{Surveys analisados}

AMARAL, O. Pesquisa Delegados do PT, realizada no $13^{\circ}$ Encontro Nacional do Partido dos Trabalhadores, São Paulo, 28 a 30 de abril de 2006. Universo: 1.053 delegados; Amostra: 289 delegados (27,4\%), metodologia: questionário autopreenchido;

NúCLEO DE OPINIÃO PÚBLICA. Fundação Perseu Abramo. Delegados do PT, realizada no $12^{\circ}$ Encontro Nacional do Partido dos Trabalhadores, Olinda, 14 a 16 dez. 2001. Universo: 538 delegados; amostra: 431 delegados (80,1\%); metodologia: questionário auto-preenchido;

. Fundação Perseu Abramo. Delegados do PT, realizada no $13^{\circ}$ Encontro Nacional do Partido dos Trabalhadores, São Paulo, 28 a 30 abr. 2006. Universo: 1.053 delegados; Amostra: 864 delegados (82\%), metodologia: questionário autopreenchido;

Fundação Perseu Abramo. Delegados do PT, realizada no $3^{\circ}$ Congresso Nacional do Partido dos Trabalhadores, São Paulo, 30 ago. a 2 out. 2007. Universo: 927 delegados; Amostra: 775 delegados (83,6\%), metodologia: entrevistas pessoais.

Oswaldo Amaral: oswaldo_amaral@yahoo.com.br

Recebido para publicação em março de 2011. Aprovado para publicação em maio de 2011. 